\title{
Effect of high iron concentrations on iron uptake and growth of a coastal diatom Chaetoceros sociale
}

\author{
Shouei Iwade ${ }^{1}$, Kenshi Kuma $^{1,2, *}$, Yutaka Isoda ${ }^{1}$, Masahiko Yoshida $^{1}$, Isao Kudo ${ }^{1,2}$, \\ Jun Nishioka ${ }^{2,3}$, Koji Suzuki ${ }^{2,4}$ \\ ${ }^{1}$ Faculty of Fisheries Sciences, Hokkaido University, 3-1-1 Minato-cho, Hakodate, Hokkaido 041-8611, Japan \\ ${ }^{2}$ Graduate School of Environmental Science, Hokkaido University, Kita 13-Nishi 8, Kita-ku, Sapporo, \\ Hokkaido 060-0813, Japan \\ ${ }^{3}$ Institute of Low Temperature Science, Hokkaido University, Kita 19-Nishi 8, Kita-ku, Sapporo, Hokkaido 060-0819, Japan \\ ${ }^{4}$ Faculty of Environmental Earth Science, Hokkaido University, Kita 10-Nishi 5, Kita-ku, Sapporo, \\ Hokkaido 060-0810, Japan
}

\begin{abstract}
The growth and iron uptake of the coastal marine diatom Chaetoceros sociale were experimentally measured in batch experiments at $10^{\circ} \mathrm{C}$ to which an acidic Fe(III) stock solution was added. The direct input of Fe(III) into the culture media induced the highest iron uptake rate ( $~ 3.4$ to $4.2 \times 10^{-16} \mathrm{~mol} \mathrm{Fe}$ cell $\left.{ }^{-1} \mathrm{~d}^{-1}\right)$ by $C$. sociale during the first day of the incubation, resulting from the supply of bioavailable inorganic Fe(III) species at levels above its expected equilibrium value ( 0.1 nmol $\mathrm{l}^{-1}$ ) with solid amorphous Fe(III) hydroxide in seawater. The iron uptake rate during the first day of incubation in solid amorphous Fe(III) hydroxide medium aged for $1 \mathrm{~d}$ at $10^{\circ} \mathrm{C}$ was approximately $50 \%$ lower than that in the direct Fe(III) input media. We used a modified approach in which further iron uptake by $C$. sociale from external iron in the direct Fe(III) input media was prevented by adding hydroxamate siderophore desferrioxamine B (DFB) during cultivation. After the addition of DFB, the highest growth rate $\left(\sim 0.5\right.$ to $\left.0.6 \mathrm{~d}^{-1}\right)$ of $C$. sociale by intracellularly stored Fe in the direct Fe(III) input media was maintained for a few days since no iron uptake was observed after the DFB addition. The growth rate was independent of the amount of intracellularly stored Fe. However, the maximal cell yields appeared to be relatively dependent on the amount of intracellularly stored Fe, suggesting the presence of a critical concentration of intracellular Fe (minimum cellular Fe for growth) for phytoplankton growth $\left(\sim 1 \times 10^{-16} \mathrm{~mol} \mathrm{Fe} \mathrm{cell}{ }^{-1}\right.$ for $C$. sociale $)$. In the present study, maximal and minimal Fe quotas were 3.4 to $4.2 \times 10^{-16}$ and $\sim 1 \times 10^{-16} \mathrm{~mol} \mathrm{Fe} \mathrm{cell}^{-1}$ (the maximal/minimal Fe ratio of 3.4 to $4.2)$, respectively. The high iron uptake and storage capacity in C. sociale allows this species to accumulate excess iron at high concentrations of bioavailable inorganic Fe species and to support up to 1.8 to 2.1 cell divisions without any additional iron uptake. In addition, we attempted to model the effect of luxury uptake on growth, as biodilution of cellular Fe eventually decreases the Fe quota to a critical threshold.
\end{abstract}

KEY WORDS: Iron uptake $\cdot$ Growth rate $\cdot$ Luxury uptake $\cdot$ Bioavailable Fe $\cdot$ Inorganic Fe species Coastal marine diatom $\cdot$ Chaetoceros sociale

\section{INTRODUCTION}

Iron supply is thought to regulate primary production in the high-nitrate low-chlorophyll (HNLC) oceanic regions such as the equatorial Pacific Ocean (Martin et al. 1994, Coale et al. 1996), the polar South- ern Ocean (Boyd et al. 2000) and the subarctic Pacific Ocean (Tsuda et al. 2003, Boyd et al. 2004) where iron fertilization mesoscale experiments were performed. A critical aspect of this relationship is the acquisition of iron by phytoplankton, which occurs through a complex series of extracellular reactions that are influ- 
enced by iron chemistry and speciation in seawater. The inorganic speciation of Fe(III) in seawater is dominated by its hydrolysis behavior and tendency to precipitate as particulate Fe(III) hydroxide. Recent studies of the Fe(III) hydroxide solubility in seawater suggest that the Fe(III) solubility is controlled by organic complexation (Kuma et al. 1996, Millero 1998, Liu \& Millero 1999, 2002, Waite 2001, Tani et al. 2003, Chen \& Wang 2004), which subsequently regulates dissolved iron concentrations in seawater (Kuma et al. 1996, 1998a, 2003, Johnson et al. 1997a,b, Archer \& Johnson 2000, Nakabayashi et al. 2001). In a previous study (Kuma et al. 1996), the iron solubility limit of fresh solid amorphous $\mathrm{Fe}(\mathrm{OH})_{3}$ (am-Fe(III)) in ultraviolet (UV)irradiated open-ocean waters (free of organic ligands) was 0.07 to $0.09 \mathrm{nmol}^{-1}\left(\leq 0.1 \mathrm{nmol} \mathrm{l}^{-1}\right)$. In addition, Wu et al. (2001) also reported that the iron solubility limit for inorganic Fe(III) hydrolysis species (Fe(III)') in the UV-irradiated seawater was $\sim 0.08 \pm 0.03 \mathrm{nmol} \mathrm{l^{-1 }}$. Therefore, the equilibrium concentration of $\sim 0.1 \mathrm{nmol}$ $\mathrm{l}^{-1}$ only applies for iron in equilibrium with a fresh amorphous solid $\mathrm{Fe}(\mathrm{OH})_{3}$ and is a maximum limit on Fe(III)' in seawater. In addition, it has been reported that the complexation of iron with natural organic ligands increases the Fe(III) solubility in seawater (Hudson et al. 1992, Kuma et al. 1999, Liu \& Millero 1999, 2002, Chen \& Wang 2004).

In general, the iron uptake rate by phytoplankton is related to the computed equilibrium concentration of $\mathrm{Fe}^{3+}$ in seawater and is actually dependent on the concentration of dissolved inorganic Fe(III) species

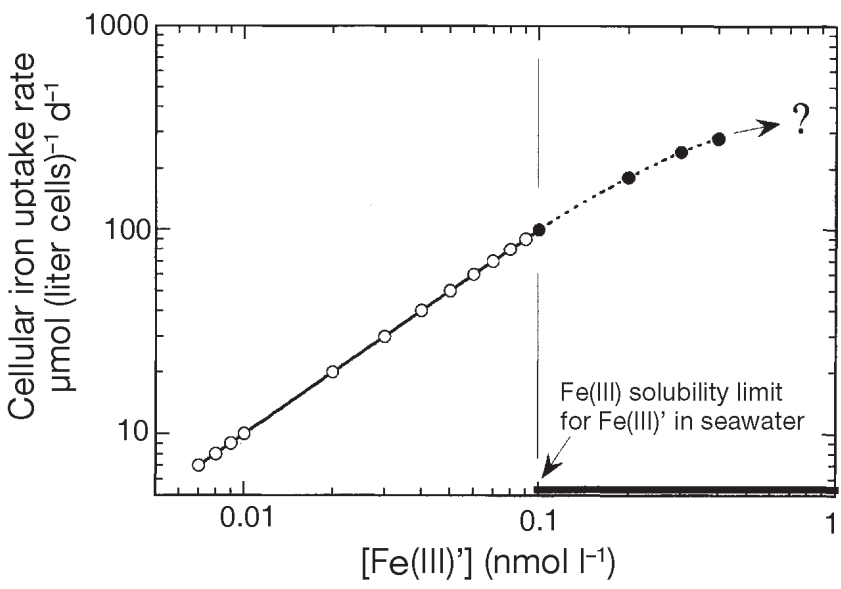

Fig. 1. Theoretical interrelationship between concentration of inorganic Fe(III) species ([Fe(III)']) and cellular iron uptake rate by phytoplankton (Campbell 1995, Sunda 2001). The solid horizontal bar on the lower right indicates the region where amorphous Fe(III) hydroxide is observed to precipitate. [Fe(III)'] should be in constant equilibrium with solid amorphous Fe(III) hydroxide in seawater. The Fe(III) solubility limit for Fe(III)' in seawater is likely to be approximately $0.1 \mathrm{nmol} \mathrm{l}^{-1}$ (Kuma et al. 1996, Wu et al. 2001). ?: unknown non-linear line for iron uptake rate over Fe(III) solubility limit
([Fe(III)'], Fig. 1), which is proportional to $\left[\mathrm{Fe}^{3+}\right]$ (Freeion activity model (FIAM); Anderson \& Morel 1982, Hudson \& Morel 1990, Campbell 1995, Sunda \& Huntsman 1995, Sunda 2001), although apparent exceptions to the FIAM exist; for example, specific transport ligands such as siderophores or lipophilic metal complexes that may be indirectly utilized by cells (Campbell 1995, Soria-Dengg \& Horstmann 1995, Hutchins et al. 1999a,b, Maldonado \& Price 1999, 2000, 2001, Sunda 2001), and a new model recently proposed by Shaked et al. (2005) for iron uptake by diatoms in which extracellular reduction of all Fe species is a necessary step for iron acquisition. Therefore, the iron uptake of phytoplankton is limited by the equilibrium concentration of Fe(III)' with particulate Fe(III) hydroxide in seawater (Fig. 1). In previous studies (Kuma et al. 1999, 2000), it has been suggested that the natural organic-Fe(III) complexes and acidic Fe(III) supplied by riverine input may play an important role in supplying bioavailable Fe(III)' above the equilibrium concentration of $\mathrm{Fe}(\mathrm{III})^{\prime}$ in estuarine mixing systems and coastal waters. A high concentration of Fe(III)' represents the actual instantaneous availability of iron for uptake. Therefore, the direct input of concentrated acidic Fe(III) or Fe(II) stock solution into culture solution or natural seawater is assumed to enhance the concentration of bioavailable inorganic Fe (Fe': Fe(III)' or Fe(II)') species above the equilibrium concentration in seawater and to induce the highest iron uptake rate and highest growth of phytoplankton. In mesoscale iron fertilization experiments, the addition of a highly concentrated acidic Fe(II) solution to the patch in HNLC oceanic regions promoted the rapid growth of large-size phytoplankton (Coale et al. 1996, Boyd et al. 2000) and coastal species (Tsuda et al. 2003). An increase in $\mathrm{Fe}^{\prime}$ in marine environments is one of the most important mechanisms for providing bioavailable Fe'.

It has been found that the addition of excess concentrations of the siderophore desferrioxamine B (DFB) essentially eliminated iron uptake in a picoplanktondominated community by diminishing the concentration of bioavailable Fe(III)' (Wells et al. 1994) and regulated iron availability in coastal upwelling waters (Hutchins et al. 1999a, Wells 1999). DFB is a small trihydroxamate molecule that complexes inorganic Fe(III) with an extremely high conditional stability constant $\left(K_{\mathrm{FeL}, \mathrm{Fe}(\mathrm{III})^{\prime}}^{\prime}=[\mathrm{Fe}(\mathrm{III}) \mathrm{L}] /\left[\mathrm{Fe}(\mathrm{III})^{\prime}\right]\left[\mathrm{L}^{\prime}\right]=10^{16.5} \mathrm{M}^{-1}\right.$; Hudson et al. 1992, Rue \& Bruland 1995) in seawater. However, it has been suggested that marine diatoms, Phaeodactylum tricornutum (Soria-Dengg \& Horstmann 1995) and iron-limited Thalassiosira oceanica (Maldonado \& Price 2000, 2001), and phytoplankton communities in the subarctic Pacific (Maldonado \& Price 1999) can utilize DFB-bound Fe(III) via a cell- 
surface reduction process. In addition, Hutchins et al. (1999b) have reported that iron bound to a variety of siderophores is more available to prokaryotic picoplankton (cyanobacteria) than to eukaryotic phytoplankton that can efficiently assimilate porphyrincomplexed iron, suggesting that the 2 plankton groups exhibit fundamentally different iron-uptake strategies.

In the present study, we examined the effect of hydroxamate siderophore DFB addition and bioavailable Fe(III)' at levels above the equilibrium concentration with solid amorphous Fe(III) hydroxide in seawater on the iron uptake and growth dynamics of coastal diatom Chaetoceros sociale. The temporary high Fe(III)' concentration in medium was accomplished by adding acidic Fe(III) stock solution directly together with an inoculation of culture into the culture medium. In addition, the growth of $C$. sociale by intracellularly stored Fe was accomplished by the addition of DFB, which prevents further iron uptake from ambient extracellular Fe in the medium. In particular, we show that the high $\mathrm{Fe}(\mathrm{III})^{\prime}$ concentration in seawater is remarkably bioavailable and induces the highest iron uptake and growth of coastal marine phytoplankton.

\section{MATERIALS AND METHODS}

Seawater was collected from a coastal region near Hokkaido, Japan, in the northern Japan Sea (salinity = 33.8), and was filtered through an acid-cleaned $0.22 \mu \mathrm{m}$ Millipore cellulose membrane filter. The filtrate $(100 \mathrm{ml})$ for Fe concentration analysis was buffered at pH 3.2 with a $10 \mathrm{~mol} \mathrm{l}^{-1}$ formic acid, $2.4 \mathrm{~mol} \mathrm{l}^{-1}$ ammonium formate buffer solution $\left(0.5 \mathrm{ml} 100 \mathrm{ml}^{-1}\right.$ filtrate). The Fe concentration in buffered filtrate $\left(\leq 2 \mathrm{nmol} \mathrm{l}^{-1}\right)$ was determined with an automated Fe analyzer (Kimoto Electric) by placing various concentrations on an 8-hydroxyquinoline chelating column and using luminol-hydrogen peroxide chemiluminescence (CL) detection in a closed flow-through system (Obata et al. 1993, 1997). The concentrations of $\mathrm{NO}_{3}+\mathrm{NO}_{2}, \mathrm{PO}_{4}$, and $\mathrm{Si}(\mathrm{OH})_{4}$ in the filtered seawater measured by a Technicon autoanalyzer were less than $0.5,0.1$, and $5 \mu \mathrm{mol} \mathrm{l}^{-1}$, respectively, which are negligible compared with the concentrations added in the culture experiments (see below). DFB (sold commercially under the trade name Desferal) was purchased from Sigma and stored frozen in the dark until use. All bottles, flasks and tubes used in our experiments were acid-washed (soaked for at least $24 \mathrm{~h}$ in 1 or $3 \mathrm{~mol} \mathrm{l}^{-1} \mathrm{HCl}$ solution: $1 \mathrm{~mol} \mathrm{l}^{-1} \mathrm{HCl}$ for polycarbonate apparatuses) followed by repeated washing with Milli-Q water (Millipore, $>18.0 \mathrm{M} \Omega \mathrm{cm}^{-1}$ ). All the preparation and sampling for experiments were performed in a Class 100 laminar flow cabinet to avoid inadvertent trace metal contamination.
Culture experiments. The filtered seawater was autoclaved for $20 \mathrm{~min}$ at $121^{\circ} \mathrm{C}\left(1.1 \mathrm{~kg} \mathrm{~cm}^{-2}\right.$ pressure), and the culture medium was prepared by adding modified f/2 nutrient (Guillard \& Ryther 1962) without trace metals and EDTA to the autoclaved filtered seawater. The modified $\mathrm{f} / 2$ medium contained $880 \mu \mathrm{mol} \mathrm{l}^{-1}$ nitrate, $38 \mu \mathrm{mol} \mathrm{l}^{-1}$ phosphate, and $105 \mu \mathrm{mol}{ }^{-1}$ silicate. The chain-forming coastal marine diatom Chaetoceros sociale was grown in $1 \mathrm{l}$ of the $\mathrm{f} / 2$ medium to which acidic ferric iron stock solution $\left(25 \mu \mathrm{mol} \mathrm{l}^{-1} \mathrm{Fe}(\mathrm{III})\right.$; $\mathrm{FeNH}_{4}\left(\mathrm{SO}_{4}\right)_{2} \cdot 12 \mathrm{H}_{2} \mathrm{O}$ in $5 \mathrm{mmol} \mathrm{l} \mathrm{l}^{-1} \mathrm{HCl}$, pH 2.3) was added to make an iron concentration of $100 \mathrm{nmol}^{-1}$. The $\mathrm{pH}$ of the seawater after the acidic iron addition was 7.98 to 8.03 . Cells were grown at $10^{\circ} \mathrm{C}$ under $150 \mu \mathrm{mol}$ photons $\mathrm{m}^{-2} \mathrm{~s}^{-1}$ fluorescent light $(12: 12 \mathrm{~h}$, light:dark) to obtain the cell concentration of C. sociale (cell diameter: $\sim 6 \mu \mathrm{m}$, height; $\sim 12 \mu \mathrm{m}$ in initial stationary growth phase) expected at the start of the following culture and iron uptake experiments.

Small amounts of acidic ferric iron stock solution (25 $\mathrm{\mu mol} \mathrm{l}^{-1} \mathrm{Fe}(\mathrm{III})$ ) and DFB solution were immediately mixed in an acid-cleaned $100 \mathrm{ml}$ polycarbonate Erlenmeyer flask. Each DFB medium was prepared by adding $50 \mathrm{ml}$ of autoclaved filtered seawater at $10^{\circ} \mathrm{C}$ to each premixed DFB-Fe(III) (molar ratios of 2.5:1, 5:1 and 10:1, pH 2.4 2.6) solution in the flask to determine which ratio of DFB:Fe(III) inhibited the growth of Chaetoceros sociale over at least $20 \mathrm{~d}$ in culture experiments. Solid am-Fe(III) medium was prepared by aging the seawater medium for $1 \mathrm{~d}$ after adding a small amount of acidic ferric iron stock solution to $50 \mathrm{ml}$ of autoclaved filtered seawater $\left(10^{\circ} \mathrm{C}\right)$. The final iron concentration was $100 \mathrm{nmol} \mathrm{l}^{-1}$. A f/2 nutrient stock solution and then a small amount of culture (ca. $250 \mu \mathrm{l}$ ) in an initial stationary growth phase (Fe-limited cells) were added to each culture flask. All major nutrient stocks were passed through Chelex 100 ion-exchange resin to remove trace metals (Morel et al. 1979). The effect of direct $\mathrm{Fe}$ input was examined by adding a small amount of acidic ferric iron stock solution directly together with an inoculation of culture into the control culture medium $\left(10^{\circ} \mathrm{C}\right)$. In addition, the effect of direct Fe(III) input and the growth by intracellular Fe were examined by the addition of DFB to a final concentration of $1 \mu^{-10 l ~ l^{-1}}$ (DFB:Fe(III) = 10:1) after 2 min and 1, 3, 5 and 7 d cultivations in direct Fe(III) input medium to prevent further iron uptake by C. sociale from ambient external Fe (dissolved Fe(III) and solid Fe(III) hydroxide in the medium). DFB was also added to C. sociale cultivated for $1 \mathrm{~d}$ in $1 \mathrm{~d}$ aged am-Fe(III) culture. Control (without any added iron) medium $\left(\leq 3 \mathrm{nmol} \mathrm{Fe}{ }^{-1}\right)$ was prepared to compare the growth rates and cell yields with those containing iron. C. sociale cell concentrations at the start of the culture experiments were approximately 1000 cells ml $\mathrm{m}^{-1}$. The 
light, temperature, and nutrient conditions were the same as those of the stock culture described above. During the experiments, cell growth was monitored daily by triplicate cell counts (actual cells and not chains) done with an optical microscope. Culture experiments were conducted in triplicate.

Iron uptake experiments. Iron uptake experiments were conducted with Chaetoceros sociale grown in direct Fe(III) input and am-Fe(III) culture to which DFB was added just after 1 and/or 3 d cultivations. The long-term $(3 \mathrm{~h}, 12 \mathrm{~h}$, and/or daily for 1 to $7 \mathrm{~d})$ iron uptake experiments were carried out in medium to which ${ }^{59} \mathrm{Fe}(\mathrm{III})$ was directly added. Incubations were done at $10^{\circ} \mathrm{C}$ under $150 \mu \mathrm{mol}$ photons $\mathrm{m}^{-2} \mathrm{~s}^{-1}$ fluorescent light.

The direct ${ }^{59} \mathrm{Fe}$ (III) input culture was prepared by adding a small volume of acidic radioactive ${ }^{59} \mathrm{Fe}(\mathrm{III})$ (New England Nuclear, NEZ-037) stock solution ( $\mathrm{pH} 2.2 \sim 2.3$ ) to 11 of autoclaved filtered seawater $\left(10^{\circ} \mathrm{C}\right)$, which already contained modified $\mathrm{f} / 2$ nutrient and the Chaetoceros sociale culture in initial stationary growth phase. The $\mathrm{pH}$ of the culture solution after acidic radioactive ${ }^{59} \mathrm{Fe}$ (III) addition was 7.98 to 8.05 . Solid am- ${ }^{59} \mathrm{Fe}$ (III) culture was prepared by adding modified $\mathrm{f} / 2$ nutrient and the $C$. sociale culture (approximately $50 \mathrm{ml}$ ), after adding acidic stock ${ }^{59} \mathrm{Fe}$ (III) solution to $950 \mathrm{ml}$ of autoclaved filtered seawater $\left(10^{\circ} \mathrm{C}\right)$ and then aging for $1 \mathrm{~d}$ at $10^{\circ} \mathrm{C}$. C. sociale cell concentration at the start of the iron uptake experiments was ca. 10000 cells $\mathrm{ml}^{-1}$. The nutrient and iron concentrations were the same as those in the culture experiments described above.

At each sample point $(3 \mathrm{~h}, 12 \mathrm{~h}$, and/or daily for 1 to $7 \mathrm{~d}$ ) during the iron uptake experiment, a $50 \mathrm{ml}$ aliquot of ${ }^{59} \mathrm{Fe}$ (III) culture solution was mixed with $20 \mathrm{ml}$ of $0.175 \mathrm{~mol} \mathrm{l}^{-1} \mathrm{Ti}(\mathrm{III})$-citrate-EDTA solution $(0.175 \mathrm{~mol}$ $\mathrm{l}^{-1} \mathrm{TiCl}_{3}, \mathrm{Na}_{3}$ citrate $\cdot 2 \mathrm{H}_{2} \mathrm{O}$, and $\mathrm{Na}_{2} \mathrm{EDTA} \cdot 2 \mathrm{H}_{2} \mathrm{O}$ in filtered seawater, followed by an adjustment of the $\mathrm{pH}$ to 8 with $\mathrm{NaOH}$ solution) in a glass beaker. The Ti(III) solution was used to rapidly dissolve freshly precipitated am-Fe(III) (Hudson \& Morel 1989, 1990) and extracellularly adsorbed iron by reductive dissolution of Fe(III) without cellular damage to Chaetoceros sociale. After the mixture had stood for $10 \mathrm{~min}$, it was gently vacuum-filtered through a quantitative filter paper (No. 5C, Advantec) that retains all precipitate $\geq 1 \mu \mathrm{m}$. The filter was rinsed with $30 \mathrm{ml}$ of $0.05 \mathrm{~mol} \mathrm{l}^{-1}$ Ti(III)-citrate-EDTA solution. The drained filter was digested with $7 \mathrm{ml}$ of conc. $\mathrm{HNO}_{3}$ :conc. $\mathrm{HClO}_{4}$ (1:1) and then diluted to $20 \mathrm{ml}$. The $\gamma$-activity of $4 \mathrm{ml}$ of diluted sample in a counting vial was measured using a gamma counter (Aloka ARC-301 B), and the results were converted to amounts and rates of iron incorporation. In addition, iron uptake experiments for cell-free control media (direct ${ }^{59} \mathrm{Fe}(\mathrm{III})$ and $\mathrm{am}-{ }^{59} \mathrm{Fe}(\mathrm{III})$ ) at $10^{\circ} \mathrm{C}$ were conducted to ascertain the reductive dissolution of freshly precipitated and aged am-Fe(III) by the Ti(III) solution. In previous studies (Kuma \& Matsunaga 1995, Kuma et al. 2000), freshly precipitated am-Fe(III) (aged for less than $1 \mathrm{~d}$ at $10^{\circ} \mathrm{C}$ ) was almost completely dissolved by the reductive dissolution with Ti(III) treatment. However, aged am-Fe(III) produced in direct $\mathrm{Fe}$ (III) input cell-free media during aging above $1 \mathrm{~d}$ at $10^{\circ} \mathrm{C}$ was incompletely reductively dissolved by the $\mathrm{Ti}$ (III) solution because of the much slower dissolution of aged am-Fe(III). The dissolution rates of the am-Fe(III) phase decrease with aging time because of the conversion to more stable phases (Kuma \& Matsunaga 1995). Therefore, iron uptake at each sample point during the iron uptake experiments was determined by subtracting the amount of insoluble iron in cell-free medium from the amount of iron uptake in medium containing cells. C. sociale cell concentrations at the start of the iron uptake experiments were approximately 10000 cells $\mathrm{ml}^{-1}$. During the experiments, cell growth in each culture was monitored by triplicate cell counts done with an optical microscope.

Hydrolytic precipitation of Fe(III) in seawater and dissolution of am-Fe(III) in seawater by adding DFB. The hydrolytic precipitation rate of Fe(III) in the $0.22 \mu \mathrm{m}$-filtered seawater was measured at 10 and $20^{\circ} \mathrm{C}$ by a simple filtration technique involving $\gamma$-activity measurement of ${ }^{59} \mathrm{Fe}$ previously reported by Kuma et al. (1996, 1998b). To examine the effect of aging time and temperature on the hydrolytic precipitation of Fe(III) in seawater, a small amount of acidic ${ }^{59} \mathrm{Fe}$ (III) stock solution was added, previously spiked with a small known amount of stable Fe(III), to $250 \mathrm{ml}$ of the $0.22 \mu \mathrm{m}$-filtered seawater in acid-cleaned $250 \mathrm{ml}$ Teflon bottles. In addition, the dissociative precipitation rate of premixed DFB-Fe(III) (10:1) complex added into the filtered seawater at $10^{\circ} \mathrm{C}$ was also measured by the same filtration method (Kuma et al. 2000). Briefly, a small amount of ${ }^{59} \mathrm{Fe}(\mathrm{III})$ stock solution and a solution of DFB were mixed in a precleaned $250 \mathrm{ml}$ bottle $\left(10^{\circ} \mathrm{C}, \mathrm{pH} 2.4\right.$ to 2.6$)$, followed by the addition of $250 \mathrm{ml}$ of filtered seawater $\left(10^{\circ} \mathrm{C}\right)$. The concentration of iron and $\mathrm{pH}$ in seawater solutions was kept constant (100 nmol $\mathrm{l}^{-1}, \mathrm{pH} 7.98$ to 8.05 ) in all experiments. In general, the addition of dissolved inorganic Fe(III) to seawater results in rapid hydrolytic precipitation of metastable Fe(III) hydroxide, which slowly converts to more stable solid phases (Kuma \& Matsunaga 1995, Stumm \& Morgan 1996). The bottles containing the seawater solution and radiolabelled Fe(III) were kept in an incubator (in the dark) at 10 or $20^{\circ} \mathrm{C}$. While standing in the dark for $3 \mathrm{wk}$ at 10 or $20^{\circ} \mathrm{C}$, each $7.5 \mathrm{ml} \mathrm{sam}$ ple aliquot was filtered through a $0.025 \mu \mathrm{m}$ Millipore cellulose membrane filter and acidified by the addition 
of $10 \mu \mathrm{l}$ of concentrated $\mathrm{HCl}$ to prevent adsorption of filtered Fe(III) on the wall of the collecting vial. The $\gamma$-activity of the $2.5 \mathrm{ml}$ acidified sample filtrates was measured in $5 \mathrm{ml}$ counting vials with a gamma counter. Finally, the $0.025 \mu \mathrm{m}$-filtered Fe(III) concentrations (Fe(III) hydroxide solubility) were calculated from the $\gamma$-activity (Kuma et al. 1996, 1998a).

Organic ligand (DFB)-promoted dissolution of solid am ${ }^{-59} \mathrm{Fe}(\mathrm{III})$ produced in the direct ${ }^{59} \mathrm{Fe}$ (III) input medium was monitored in the cell-free control and cell-containing culture medium at $10^{\circ} \mathrm{C}$ during the iron uptake experiments. Dissolution of am${ }^{59} \mathrm{Fe}(\mathrm{III})$ was measured on a daily basis using a simple filtration technique involving $\gamma$-activity measurement of ${ }^{59} \mathrm{Fe}$ following the same procedure as the hydrolytic precipitation experiments as described above.

\section{RESULTS}

\section{Growth rate and cell yields}

In the present study, direct Fe(III) input to the culture solution induced the highest growth rate $\left(0.55\right.$ to $0.58 \mathrm{~d}^{-1}$, Table 1 , Fig. 2A) and the highest maximal cell yields (141000 to 147000 cells $\mathrm{ml}^{-1}$, Table 1), showing values similar to those in the same medium in the previous study (Kuma et al. 2000). The relative order for growth rates and maximal cell yields on different media
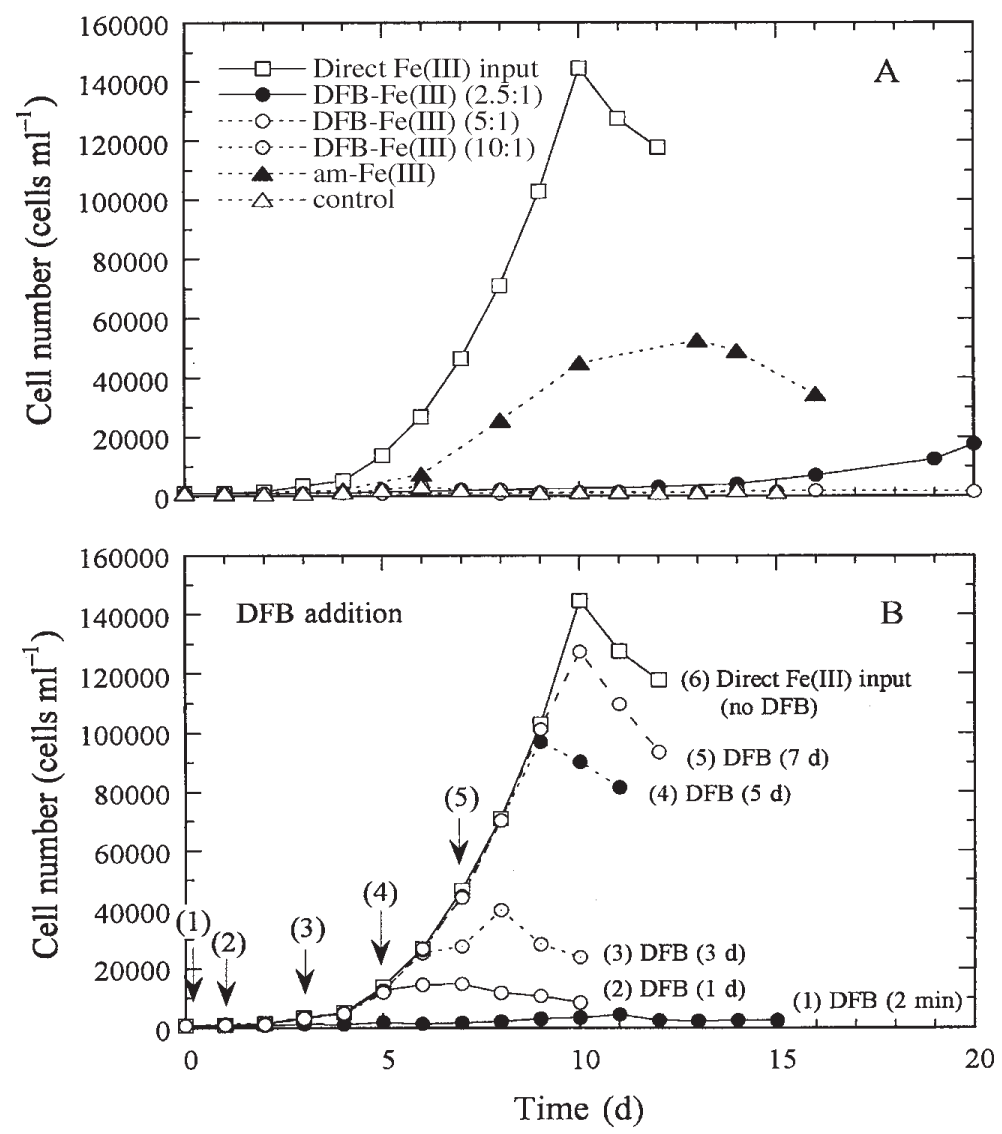

Fig. 2. Chaetoceros sociale. Change in cell numbers of cultures supplied with direct $\mathrm{Fe}$ (III) input, premixed DFB (desferrioxamine B)-Fe(III) complex and solid am-Fe(III) (amorphous $\left.\mathrm{Fe}(\mathrm{OH})_{3}\right)\left(10^{\circ} \mathrm{C}\right)$. (A) Growth in direct Fe(III) input, premixed DFB-Fe(III) complex (2.5:1, 5:1 and 10:1), solid am$\mathrm{Fe}(\mathrm{III})$ and control (no iron addition) media. (B) Growth in direct Fe(III) input medium without or with addition of DFB after 2 min and 1, 3, 5 and 7 d. Data on cell concentrations represent the mean $(n=3)$ for triplicate culture experiments

Table 1. Chaetoceros sociale. Growth rate and maximal cell yields (see Figs. 2B \& 3 ) in direct Fe(III) input and $1 \mathrm{~d}$ aged am-Fe(III) (amorphous $\mathrm{Fe}(\mathrm{OH})_{3}$ ) media $\left(10^{\circ} \mathrm{C}\right.$ ) to which DFB (desferrioxamine B) was added after incubation for 1 or $3 \mathrm{~d}(\mathrm{DFB}: \mathrm{Fe}(\mathrm{III})=10: 1)$. $\mathrm{N}$ : not determined (range given for $\mathrm{A}$ and $\pm 1 \mathrm{SD}$ for $\mathrm{B}$ )

\begin{tabular}{|c|c|c|c|c|}
\hline Medium & $\begin{array}{l}\text { Cell number } \\
\text { at start } \\
\left(10^{3} \text { cells } \mathrm{ml}^{-1}\right)\end{array}$ & $\begin{array}{l}\text { Addition of DFB } \\
\qquad\left(1 \mu \mathrm{mol} \mathrm{l} 1^{-1}\right)\end{array}$ & $\begin{array}{l}\text { Specific growth rate } \\
\qquad\left(\mu, \mathrm{d}^{-1}\right)\end{array}$ & $\begin{array}{c}\text { Maximal cell } \\
\text { yields }[\mathrm{Cn}] \\
\left(\times 10^{3} \text { cells } \mathrm{ml}^{-1}\right)\end{array}$ \\
\hline \multicolumn{5}{|c|}{ (A) Growth rate experiment ( $\mathrm{n}=3$, Fig. 2B) } \\
\hline Direct Fe(III) & 1 & No addition & $0.55-0.56(0-10 \mathrm{~d})$ & $141-147$ \\
\hline Direct Fe(III) & 1 & After $7 \mathrm{~d}$ incubation & $0.57-0.58(0-9 \mathrm{~d})$ & $124-130$ \\
\hline Direct Fe(III) & 1 & After $5 \mathrm{~d}$ incubation & $0.56-0.57(0-8 \mathrm{~d})$ & $93-101$ \\
\hline Direct Fe(III) & 1 & After $3 \mathrm{~d}$ incubation & $0.55-0.57(0-6 \mathrm{~d})$ & $39-40$ \\
\hline Direct Fe(III) & 1 & After $1 \mathrm{~d}$ incubation & $0.49-0.52(0-5 \mathrm{~d})$ & $13-17$ \\
\hline Direct Fe(III) & 1 & After 2 min incubation & $\mathrm{N}$ & $\mathrm{N}$ \\
\hline \multicolumn{5}{|c|}{ (B) Iron uptake and growth rate experiment (n = 1, Fig. 3) } \\
\hline Direct Fe(III) & 10 & No addition & $0.50 \pm 0.01(0-5 \mathrm{~d}, \mathrm{r}=0.999)$ & $126 \pm 20$ \\
\hline Direct Fe(III) & 10 & After $3 \mathrm{~d}$ incubation & $0.47 \pm 0.01(0-4 \mathrm{~d}, \mathrm{r}=0.999)$ & $66 \pm 4.5$ \\
\hline Direct Fe(III) & 10 & After $1 \mathrm{~d}$ incubation & $0.46 \pm 0.02(0-3 \mathrm{~d}, \mathrm{r}=0.999)$ & $52 \pm 1.7$ \\
\hline $1 \mathrm{~d}$ am-Fe(III) & 10 & After $1 \mathrm{~d}$ incubation & $0.45 \pm 0.05(0-2 \mathrm{~d}, \mathrm{r}=0.994)$ & $43 \pm 2.2$ \\
\hline
\end{tabular}


for 10 to 20 d cultivations was Direct Fe(III) input $>>$ solid 1 d aged am-Fe(III) $>$ DFB-Fe(III) (2.5:1) > DFB-Fe(III) (5:1 and 10:1) = control (Fig. 2A). No growth of Chaetoceros sociale was observed in DFB-Fe(III) (5:1 and 10:1) and control (no iron addition) media (Fig. 2A). Therefore, the effect of direct Fe(III) input on $C$. sociale growth and growth by intracellularly stored Fe were examined by the addition of DFB (final concentration of $1 \mu \mathrm{mol} \mathrm{l^{-1 }}$, DFB:Fe(III) = 10:1) during cultivation to prevent iron uptake from ambient extracellular Fe. DFB was added to $C$. sociale cultivated for $2 \mathrm{~min}$ (DFB (2 min) medium), $1 \mathrm{~d}$ (DFB (1 d) medium), 3 d (DFB (3 d) medium), $5 \mathrm{~d}$ (DFB (5 d) medium) and $7 \mathrm{~d}$ (DFB (7 d) medium) in direct Fe(III) input culture medium (Fig. 2B). No growth was observed in the DFB (2 min) culture medium. However, the growth in other media continued for 3 to $4 \mathrm{~d}$ even after the addition of DFB with almost the same maximum growth rate $\left(\sim 0.5\right.$ to $\left.0.6 \mathrm{~d}^{-1}\right)$ as that in direct Fe(III) input medium without any addition of DFB. Cell concentration in the DFB (1 d) medium increased up to approximately 15000 cells ml ${ }^{-1}, 15$ times more than the initial cell concentration, after 5 to $6 \mathrm{~d}$ of cultivation after the addition of DFB (Fig. 2B). The relative order for maximal cell yields was direct Fe(III) input $>$ DFB (7 d) > DFB (5 d) > DFB (3 d) > DFB (1 d) media, while the initial growth rates were almost the same in all media (Fig. 2B, Table 1).

\section{Iron uptake and growth rate}

The long-term radiolabelled iron uptake rates by Chaetoceros sociale and the growth in direct Fe(III) input and am-Fe(III) media, into which DFB was added after 1 and/or 3 d cultivations, were measured during cultivation for $7 \mathrm{~d}$ at $10^{\circ} \mathrm{C}$ (Fig. 3). The cellular iron uptake ( $\mathrm{nmol} \mathrm{l}^{-1}$ ) by C. sociale in all media was prevented by the addition of DFB and remained nearly constant for 2 to $4 \mathrm{~d}$ after DFB treatment (Fig. 3A). However, after $5 \mathrm{~d}$ the cells reached stationary phase and thus iron uptake rates decreased (Fig. 3). In the direct Fe(III) input medium, the iron uptake rate decreased gradually with cultivation time for 0 to $3 \mathrm{~d}$ before DFB addition and the highest rate
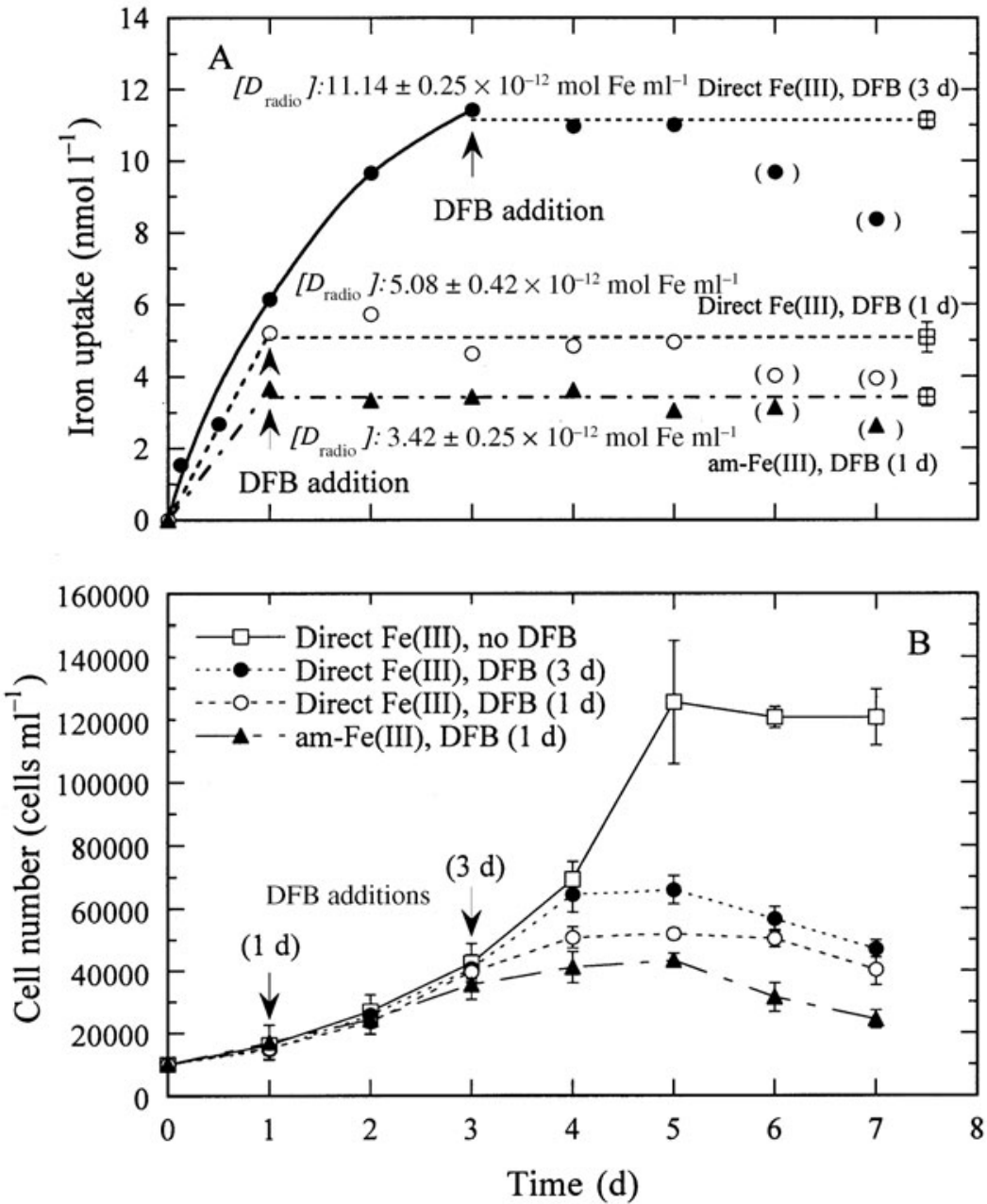

Fig. 3. Chaetoceros sociale. Long-term iron uptake and growth in direct Fe(III) input media and $1 \mathrm{~d}$ aged am-Fe(III) medium without or with addition of DFB after 1 and/or 3 d cultivations. (A) Iron uptake rates by C. sociale in direct $\mathrm{Fe}$ (III) medium with addition of DFB after $1 \mathrm{~d}$. Radiolabelled iron uptake $\left[D_{\text {radio }}\right]$ reprets mean $\pm 1 \mathrm{SD}$ for values from 1 to $5 \mathrm{~d}$ in the DFB (1 d) media and from 3 to aged am-Fe(III) medium without or with addition of DFB after 1 and/or $3 \mathrm{~d}$. Data on cell concentrations represent mean $\pm 1 \mathrm{SD}(\mathrm{n}=3)$ for triplicate cell counts was observed during the initial iron uptake during 0 to $1 \mathrm{~d}$. The iron uptake rate during 0 to $1 \mathrm{~d}$ in $1 \mathrm{~d}$ aged am-Fe(III) medium was approximately one-third lower than those during 0 to $1 \mathrm{~d}$ and almost the same as that during 1 to $2 \mathrm{~d}$ in direct Fe(III) input medium. The order of iron uptake was: DFB $(3 \mathrm{~d})>\operatorname{DFB}(1 \mathrm{~d})>$ am-Fe(III)-DFB (1 d) (Fig. 3A, Tables $1 \& 2$ ). If cells are under identical steady state growth conditions both before and after addition of radiolabelled $\mathrm{Fe}$, it is necessary to allow the phytoplankton to go through 8 successive transfers in order to measure intracellular Fe quotas by radioactive ${ }^{59} \mathrm{Fe}$ uptake, so that the Fe within the cells was $100 \%$ radiolabelled,. The initial cultures in the iron uptake experiments had a cell density of 10000 cells $\mathrm{ml}^{-1}$. The growth rate was 
Table 2. Chaetoceros sociale. Iron uptake (see Fig. 3) in direct Fe(III) and $1 \mathrm{~d}$ aged am-Fe(III) media $\left(10^{\circ} \mathrm{C}\right)$ to which DFB was added after incubation for 1 or $3 \mathrm{~d}$. Values of [Q] for the direct Fe(III) input medium (DFB (1 d)) and $1 \mathrm{~d}$ aged am-Fe(III) medium (DFB (1 d)) are also the corrected iron uptake rate with units of mol Fe cell ${ }^{-1} \mathrm{~d}^{-1}$

\begin{tabular}{|c|c|c|c|c|c|}
\hline Medium & $\begin{array}{c}\text { Radiolabelled Fe } \\
\text { uptake (for } 1,2 \text { or } 3 \mathrm{~d}) \\
{\left[D_{\text {radio }}\right]} \\
\left(\times 10^{-12} \mathrm{~mol} \mathrm{Fe} \mathrm{ml}^{-1}\right)\end{array}$ & $\begin{array}{c}\text { Cell density when } \\
\text { DFB was added } \\
{\left[C_{\mathrm{DFB}}\right]} \\
\left(\times 10^{3} \text { cells ml }{ }^{-1}\right)\end{array}$ & $\begin{array}{c}\text { Maximal cell } \\
\text { yields }[\mathrm{Cn}] \\
\left(\times 10^{3} \text { cells } \mathrm{ml}^{-1}\right)\end{array}$ & $\begin{array}{r}\text { Cellular Fe } \\
\text { (Fe quota: }[Q]) \\
{\left[D_{\text {radio }}\right] /\left[C_{\mathrm{DFB}}\right]} \\
\left(\times 10^{-16}\right.\end{array}$ & $\begin{array}{c}\text { Critical cellular Fe } \\
{\left[Q_{\text {cri }}\right]} \\
{\left[D_{\text {radio }}\right] /[\mathrm{Cn}]} \\
\left.\text { mol Fe cell }{ }^{-1}\right)\end{array}$ \\
\hline \multicolumn{6}{|c|}{ Iron uptake and growth rate experiment (cell density at start: $10000, \mathrm{n}=1$, Fig. 3 ) } \\
\hline \multirow[t]{3}{*}{ Direct Fe(III)-DFB-3 d } & $6.14\left(1 \mathrm{~d}^{\mathrm{a}}\right)$ & $14.8 \pm 1.7\left(1 \mathrm{~d}^{\mathrm{a}}\right)$ & $66 \pm 4.5$ & $\sim 4.15^{\mathrm{a}}$ & $\sim 0.93^{\mathrm{a}}$ \\
\hline & $9.66\left(2 \mathrm{~d}^{\mathrm{a}}\right)$ & $25.9 \pm 2.8\left(2 \mathrm{~d}^{\mathrm{a}}\right)$ & $66 \pm 4.5$ & $\sim 3.73^{\mathrm{a}}$ & $\sim 1.46^{\mathrm{a}}$ \\
\hline & $11.14 \pm 0.25(3 \mathrm{~d})$ & $40.7 \pm 4.5(3 \mathrm{~d})$ & $66 \pm 4.5$ & $2.73 \pm 0.07$ & $1.69 \pm 0.16$ \\
\hline Direct Fe(III)-DFB-1 d & $5.08 \pm 0.42(1 \mathrm{~d})$ & $15.2 \pm 3.4$ & $52 \pm 1.7$ & $3.35 \pm 0.27$ & $0.98 \pm 0.11$ \\
\hline $1 \mathrm{~d}$ am-Fe(III)-DFB-1 d & $3.42 \pm 0.25(1 \mathrm{~d})$ & $17 \pm 5.6$ & $43 \pm 2.2$ & $2.01 \pm 0.14$ & $0.80 \pm 0.10$ \\
\hline
\end{tabular}

approximately 1 division $\mathrm{d}^{-1}$ (Fig. 3B). Thus, after $1 \mathrm{~d}$, the cell density will increase to 20000 cells $\mathrm{ml}^{-1}$ and cells will be $50 \%$ radiolabelled. In the next cell division, the Fe within the cells will be $75 \%$ radiolabelled and the cell density will reach 40000 cells $\mathrm{ml}^{-1}$. Therefore, if the cells are collected before undergoing 8 divisions, the intracellular Fe concentrations which were measured with radioactive Fe need to be corrected for the non-radioactive (cold) Fe in the cells at the beginning of the experiment. However, the iron uptake experiments in the present study were started with Fe-limited cells, which are documented to have higher iron uptake rates than Fe replete cells under excessive Fe(III)' conditions. Sunda \& Huntsman (1995) reported that relative ratios of Fe replete and limiting quotas in oceanic and coastal phytoplankton are roughly 10 to 20 in a long-term iron uptake experiment. For example, if Fe limited cells contained 10 amol Fe cell ${ }^{-1}$ before the addition of excessive $\mathrm{Fe}^{\prime}$, and the steady state quota $(Q)$ with excessive $\mathrm{Fe}^{\prime}$ is 100 to $200 \mathrm{amol} \mathrm{Fe} \mathrm{cell}{ }^{-1}$, with a specific growth rate $(\mu)$ of $0.7 \mathrm{~d}^{-1}$, then the steady state uptake rate under the excessive $\mathrm{Fe}^{\prime}$ conditions is $\mu \times$ $Q=70$ to 140 amol Fe cell ${ }^{-1} \mathrm{~d}^{-1}$. Thus, after $1 \mathrm{~d}$, the Fe within the cells would be nearly 100\% ( 93 to $97 \%$ ) radiolabelled.

Cell concentrations in DFB-added media increased logarithmically for 1 to $2 \mathrm{~d}$ even after addition of DFB (Fig. 3B). The growth rates $(0.45 \pm 0.05$ to $0.47 \pm$ $\left.0.01 \mathrm{~d}^{-1}\right)$ in DFB-added medium were the same as that $\left(0.50 \pm 0.01 \mathrm{~d}^{-1}\right)$ in direct Fe(III) input medium without addition of DFB (Table 1). However, the maximal cell yields in DFB-added medium were onethird to one-half lower than that in direct Fe(III) input medium without any addition of DFB. The order of maximal cell yields was: direct Fe(III) input (no DFB) > DFB (3 d) > DFB (1 d) > am-Fe(III)$\operatorname{DFB}(1 \mathrm{~d})$.

\section{Hydrolytic precipitation of Fe(III) and organic ligand-promoted dissolution of am-Fe(III) by addition of DFB}

The hydrolytic precipitation rates of $\mathrm{Fe}^{3+}$ in filtered seawater were extremely fast, resulting in extremely low $0.025 \mu \mathrm{m}$ filterable (dissolved) Fe concentrations within short aging times (Fig. 4A). For example, the dissolved $\mathrm{Fe}$ concentrations with $1 \mathrm{~d}$ aging were 6.2 and $1.9 \mathrm{nmol}^{-1}$ at 10 and $20^{\circ} \mathrm{C}$, respectively (initial Fe added: $100 \mathrm{nmol}^{-1}$ ). In addition, the hydrolytic precipitation rate of $\mathrm{Fe}^{3+}$ at $10^{\circ} \mathrm{C}$ was slower than that at $20^{\circ} \mathrm{C}$. The dissolved Fe concentrations at $10^{\circ} \mathrm{C}$ decreased gradually (1.98 to $0.74 \mathrm{nmol} \mathrm{l}^{-1}$ ) during aging for 1 to $3 \mathrm{wk}$, while those at $20^{\circ} \mathrm{C}$ were nearly constant (within the range 0.26 to $0.36 \mathrm{nmol} \mathrm{l}^{-1}$ ) during 1 to $3 \mathrm{wk}$. Total (unfiltered) Fe concentrations decreased gradually with aging time over $3 \mathrm{wk}$ up to $\sim 50$ to $60 \mathrm{nmol} \mathrm{l}^{-1}$ because of the sorption of hydrolytic precipitated $\mathrm{Fe}$ (particulate $\mathrm{Fe}$ ) on the wall of Teflon bottles (data not shown). The long-term dissolved (soluble) iron concentrations of $\sim 0.3 \mathrm{nmol} \mathrm{l}^{-1}$ are most likely due to the presence of soluble iron organic species as mentioned above. In contrast, precipitation (loss from solution) from DFB-Fe(III) (10:1) complex in seawater was not observed during aging for $10 \mathrm{~d}$ at $10^{\circ} \mathrm{C}$ (Fig. 4B). In addition, Fig. 4B presents the organic ligand (DFB)-promoted dissolution rates of solid am-Fe(III) produced in direct Fe(III) input media (DFB (1 d) and DFB (3 d)), which were aged for 1 and $3 \mathrm{~d}$ at $10^{\circ} \mathrm{C}$ during the iron uptake experiments. There was almost no difference between the cell-free control and the cell-containing medium. The rates of DFB-promoted dissolution were relatively fast for $1 \mathrm{~d}$ after the addition of DFB and then became slower with time. DFB-promoted dissolution rate of $1 \mathrm{~d}$ aged am-Fe(III) was faster than that of $3 \mathrm{~d}$ aged am-Fe(III). 

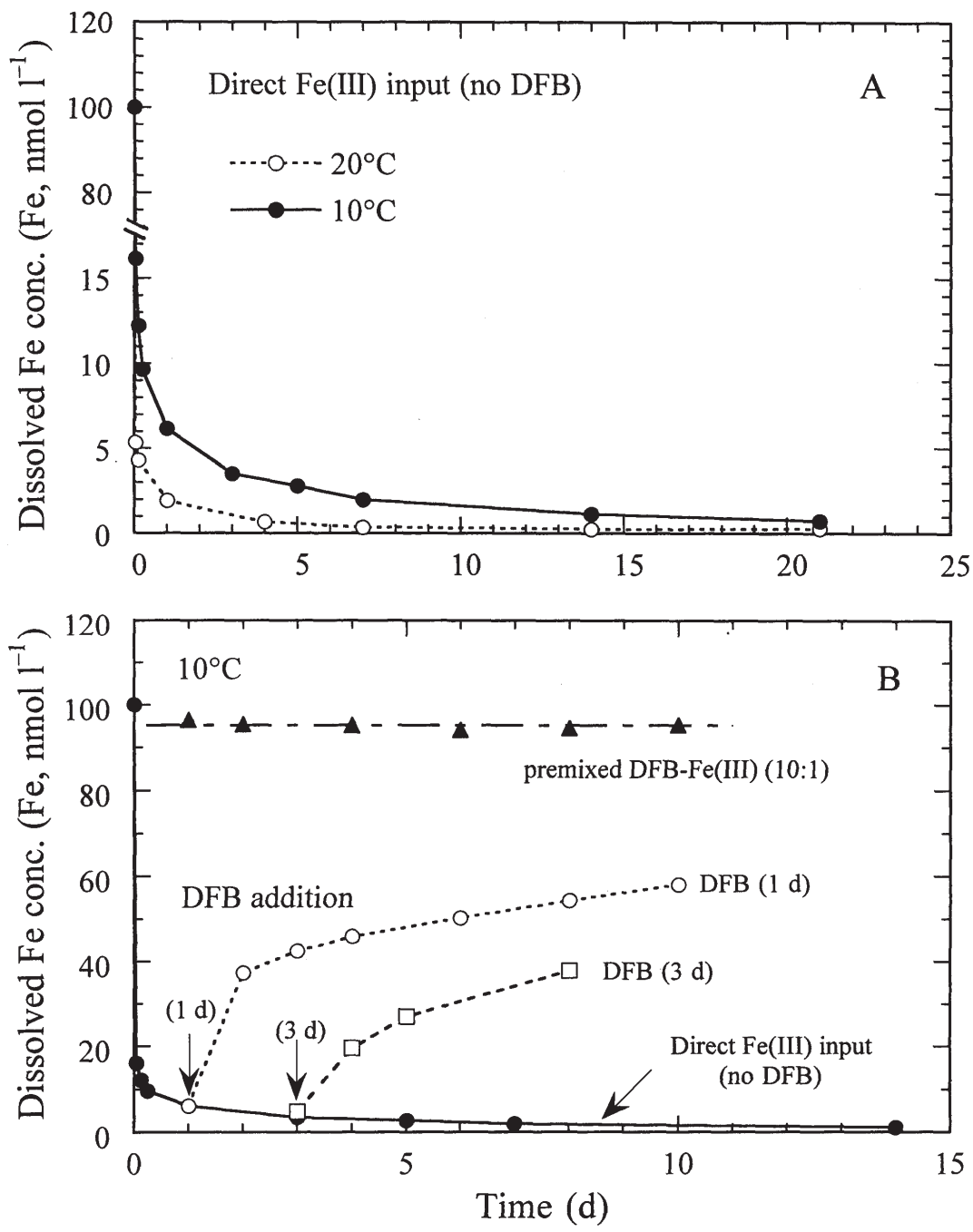

Fig. 4. Time-course of hydrolytic precipitation of $\mathrm{Fe}^{3+}, \mathrm{Fe}(\mathrm{III})$ dissociative precipitation of premixed DFB-Fe(III) complex and organic ligand (DFB)-promoted dissolution of solid aged am-Fe(III). (A) Hydrolytic precipitation rate of $\mathrm{Fe}^{3+}$ in seawater at $10^{\circ} \mathrm{C}$ and $20^{\circ} \mathrm{C}$. (B) $\mathrm{Fe}$ (III) dissociative precipitation of premixed DFB-Fe(III) (10:1) complex in seawater $\left(10^{\circ} \mathrm{C}\right)$ and DFB-promoted dissolution of solid 1 and $3 \mathrm{~d}$ aged am-Fe(III) in culture media $\left(10^{\circ} \mathrm{C}\right)$

\section{DISCUSSION}

\section{Biological effect of high bioavailable Fe level}

No growth was observed in premixed DFB-Fe(III) (5:1 and 10:1) complex and control media (Fig. 2A) and in DFB (2 min) culture medium (Fig. 2B). Therefore, cells inoculated into the culture and iron uptake experiments were iron-limited. The cells collected at an initial stationary growth phase ( 9 to $10 \mathrm{~d}$ cultivation in the direct $\mathrm{Fe}(\mathrm{III})$ input medium) were iron-limited because of the rapid decrease in bioavailability of hydrolytic precipitated Fe with time in the medium (Kuma \& Matsunaga 1995).
Direct Fe(III) input medium promoted the maximal cell yields and growth rate (Fig. 2A). In general, iron uptake rate by marine eukaryotic phytoplankton is related to the concentration of kinetically labile inorganic Fe species (Fe': Fe(II)' and $\left.\mathrm{Fe}(\mathrm{III})^{\prime}\right)$, which is proportional to $\left[\mathrm{Fe}^{2+}\right]$ and $\left[\mathrm{Fe}^{3+}\right]$, respectively (Fig. 1), and independent of the concentration of $\mathrm{Fe}$ chelated to organic ligands such as EDTA and DFB (Campbell 1995, Sunda \& Huntsman 1995, Sunda 2001) although the iron uptake rates from DFB-Fe complex by iron-limited phytoplankton are more strongly correlated to the concentrations of the DFB-Fe complex than those of $\mathrm{Fe}^{\prime}$ (Maldonado \& Price 2000, 2001). The stable oxidation state of iron in oxic seawater is Fe(III), which has an extremely low solubility. The equilibrium concentration of Fe(III)' with particulate $\mathrm{Fe}(\mathrm{III})$ hydroxide in seawater is approximately $0.1 \mathrm{nmol} \mathrm{l}^{-1}$ (Kuma et al. 1996, Wu et al. 2001), which limits the iron uptake of phytoplankton. In fact, the maximal cell yields in $1 \mathrm{~d}$ aged am-Fe(III) medium was twothirds lower than the direct Fe(III) input medium (Fig. 2A). In addition, equilibrium calculations in premixed DFB-Fe(III) (5:1 and 10:1, Fe(III) = $100 \mathrm{nmol} \mathrm{l}^{-1}$ ) media indicate that bioavailable $\mathrm{Fe}(\mathrm{III})^{\prime}$ would be limited to $\sim 10^{-17} \mathrm{~mol} \mathrm{l}^{-1}\left(K_{\mathrm{FeL}, \mathrm{Fe}(\mathrm{III})^{\prime}}^{\prime}=10^{16.5} \mathrm{M}^{-1}=\right.$ $[\mathrm{Fe}(\mathrm{III}) \mathrm{L}] /\left[\mathrm{Fe}(\mathrm{III})^{\prime}\right]\left[\mathrm{L}^{\prime}\right]$, Rue \& Bruland 1995, Croot \& Johansson 2000), or several orders of magnitude below the levels needed to support phytoplankton growth. In the present study, the direct input of Fe(III) into the culture media containing phytoplankton induced the highest radiolabelled iron uptake rate $\left(\sim 3.4 \times 10^{-16} \mathrm{~mol} \mathrm{Fe} \mathrm{cell}{ }^{-1} \mathrm{~d}^{-1}\right.$, Fig. 3A, Table 2) by Chaetoceros sociale during the first day of incubation in the long-term iron uptake experiment, resulting from the high supply of Fe(III)'. In addition, the highest radiolabelled iron uptake rate $\left(\sim 3 \times 10^{-17} \mathrm{~mol} \mathrm{Fe} \mathrm{cell}{ }^{-1} \mathrm{~h}^{-1} \times 24 \mathrm{~h}=\sim 7 \times 10^{-16} \mathrm{~mol} \mathrm{Fe}\right.$ cell ${ }^{-1} \mathrm{~d}^{-1}$ ) was also observed during the short-term iron uptake experiment with $C$. sociale in the direct Fe(III) input medium in our previous study (Kuma et al. 2000). The short-term iron uptake rate exceeded the long-term uptake rate (Fig. 3A), probably suggesting that the inoculated cells were iron-limited 
before the start of culture and iron uptake experiments in the present study. In addition, the long-term cellular radiolabelled iron uptake rate by $C$. sociale (cell diameter: $\sim 7$ to $10 \mu \mathrm{m}$, smaller than that $[\sim 12$ $\mu \mathrm{m}]$ for Thalassiosira weissflogii normalized to equivalent spherical cell surface area was 1 to $2 \times 10^{-6} \mathrm{~mol}$ Fe $\mathrm{m}^{-2} \mathrm{~d}^{-1}$, nearly consistent with rates for coastal and oceanic phytoplankton (T. weissflogii, T. pseudonana, T. oceanica and Prorocentrum minimum) at the high $\mathrm{Fe}^{\prime}$ concentrations in previous studies (Sunda \& Huntsman 1995, 1997). Therefore, the direct input of concentrated acidic Fe(III) stock solution into culture media temporarily enhances the concentration of Fe(III)' above the equilibrium concentration $(\sim 0.1$ nmol $\mathrm{l}^{-1}$ ) with solid amorphous Fe(III) hydroxide in seawater and induces the highest iron uptake and growth rates of phytoplankton, although the hydrolytic precipitation rate of $\mathrm{Fe}^{3+}$ in seawater was extremely fast (Fig. 4A).

Our results and interpretations also suggest that the natural organic-Fe(III) complexes (Fe(III)-L) and acidic Fe(III) supplied by riverine input may play an important role in supplying Fe(III)' in estuarine mixing systems and coastal waters (Stumm \& Morgan 1996, Kuma et al. 1999, 2000) as follows:

$$
\mathrm{Fe}(\mathrm{III})-\mathrm{L} \stackrel{k_{\mathrm{i}}}{\longrightarrow} \mathrm{Fe}(\mathrm{III})^{\prime} \stackrel{k_{\mathrm{ii}}}{\longrightarrow} \mathrm{Fe}(\mathrm{III}) \text { hydroxide }
$$

In addition, temporary high concentrations of Fe(II)' and Fe(III)' in seawater would have been caused by the supply of concentrated acidic Fe(II) solution (approximately $0.5 \mathrm{~mol} \mathrm{l}^{-1} \mathrm{Fe}(\mathrm{II})$ at about $\mathrm{pH} \mathrm{2)}$ to HNLC oceanic regions in mesoscale iron fertilization experiments (Martin et al. 1994, Coale et al. 1996, Boyd et al. 2000, Tsuda et al. 2003). In oxic seawater, the oxidation rate of $\mathrm{Fe}(\mathrm{II})$ is strongly dependent upon $\mathrm{pH}$ and temperature (Millero et al. 1987). In addition, a longer half-life can be expected when there is organic complexation (Santana-Casiano et al. 2000) and/or lower temperature (Kuma et al. 1995, Croot et al. 2001, Croot \& Laan 2002). For example, the half-lives of Fe(II) in seawater are approximately 10, 7, and $5 \mathrm{~min}$ at 5, 10, and $15^{\circ} \mathrm{C}$, respectively (Kuma et al. 1995). In addition, the oxidative hydrolytic precipitation of Fe(II) in seawater is given by:

$$
\mathrm{Fe}(\mathrm{II})^{\prime} \stackrel{k_{\mathrm{iii}}}{\longrightarrow} \mathrm{Fe}(\mathrm{III})^{\prime} \stackrel{k_{\mathrm{iv}}}{\longrightarrow} \mathrm{Fe}(\mathrm{III}) \text { hydroxide }
$$

Eqs. (1) \& (2) are termed consecutive reactions where the rate constants of individual steps are such that all steps must be considered. Eqs. (1) \& (2) consider the time-dependent concentrations of the intermediate products, and the final product (Brezonik 1994). The concentrations of the intermediate product (Fe(III)') reach a maximum at some intermediate time and would be temporarily above the solubility equilibrium concentration of $\mathrm{Fe}(\mathrm{III})^{\prime}$ with solid Fe(III) hydroxide in seawater. The maximum concentrations of Fe(III)' depend on the relative sizes of $k_{\mathrm{i}}$ and $k_{\mathrm{ii}}$ in Eq. (1) and $k_{\text {iii }}$ and $k_{\text {iv }}$ in Eq. (2).

\section{Growth by intracellularly stored Fe}

In the present study, the highest specific growth rate of Chaetoceros sociale was maintained for 2 to $4 \mathrm{~d}$ even after the addition of DFB, which prevented further iron uptake from ambient extracellular $\mathrm{Fe}$ in the culture media (Figs. 2B \& 3B). The growth rate was relatively independent of the amount of intracellularly stored $\mathrm{Fe}$ (Fig. 3, Tables 1 \& 2). The value of intracellular Fe ([Q]) was simply calculated by dividing the amount of radiolabelled Fe uptake ([ $\left.D_{\text {radio }}\right]$ ) for 1 or $3 \mathrm{~d}$ by cell density ( $\left.\left[C_{\mathrm{DFB}}\right]\right)$ when DFB was added for the Fe uptake measurements (Fig. 3, Table 2). Values of [ $\left.D_{\text {radio }}\right]$ and [Q] for the direct $\mathrm{Fe}(\mathrm{III})$ input and $1 \mathrm{~d}$ aged am-Fe(III) media (DFB (1 d)) are also the iron uptake rates with units of mol Fe ml $\mathrm{m}^{-1} \mathrm{~d}^{-1}$ and mol Fe cell ${ }^{-1} \mathrm{~d}^{-1}$, respectively. The intracellular $\mathrm{Fe}([Q])$ in culture media ranged from 2 to $3.4 \times 10^{-16} \mathrm{~mol} \mathrm{Fe} \mathrm{cell}{ }^{-1}$ (Table 2). The critical concentration of intracellular Fe ([ $\left.\left.Q_{\text {cri }}\right]\right)$ for phytoplankton growth was simply calculated by dividing $\left[D_{\text {radio }}\right]$ by maximal cell yields ([Cn]) (minimum cellular Fe on growth: $\left[Q_{\text {cri }}\right]=\left[D_{\text {radio }}\right] /[C n]=\sim 1 \times 10^{-16}$ mol Fe cell ${ }^{-1}$ except for the value $\left(1.7 \times 10^{-16} \mathrm{~mol} \mathrm{Fe}\right.$ cell $^{-1}$ ) obtained in the direct Fe(III) input (DFB (3 d)) medium, Table 2$)$. The higher $\left[Q_{\text {cri }}\right]$ for the direct Fe(III) (DFB (3 d)) medium is probably due to the overestimate of $\left[D_{\text {radio }}\right]$ because of the incomplete reductive dissolution of $3 \mathrm{~d}$ aged hydrolytic precipitated amFe(III) by Ti(III) treatment (Kuma \& Matsunaga 1995, Yoshida et al. 2005).

At high iron concentrations, phytoplankton can often accumulate an excess of iron than that needed to support maximum growth. Such luxury uptake at high iron concentrations was observed in a culture experiment of oceanic and coastal eukaryotic algae (Sunda \& Huntsman 1995, 1997, Sunda 2001). In the present study, the higher iron uptake rates $\left(\sim 3.4 \times 10^{-16}\right.$ and $4.2 \times 10^{-16} \mathrm{~mol} \mathrm{Fe}$ cell $\left.{ }^{-1} \mathrm{~d}^{-1}\right)$ by Chaetoceros sociale were observed during the first day of incubation in the direct Fe(III) input media and were 1.5 to 2 times higher than that in $1 \mathrm{~d}$ aged am-Fe(III) medium (Fig. 3A, Table 2). The iron uptake rate by eukaryotic phytoplankton is generally dependent on the concentration of dissolved Fe(III)' (Anderson \& Morel 1982, Campbell 1995) although a new model for iron uptake through the extracellular reduction of all Fe species was recently proposed by Shaked et al. (2005). Therefore, the higher iron uptake rates would have been accomplished at a high iron concentration of bioavailable Fe(III)' above the equilibrium concentration 
$\left(\sim 0.1 \mathrm{nmol} \mathrm{l}^{-1}\right)$ with solid amorphous Fe(III) hydroxide in seawater during the initial incubation after the direct input of Fe(III) into the culture media. Sunda \& Huntsman $(1995,1997)$ reported that the maximum iron accumulation in an oceanic coccolithophore and in coastal dinoflagellates was 2 to 3 times the amounts needed to support maximum growth rates, but substantially higher luxury uptake was observed in diatoms. In the present study, maximum iron accumulation (higher intracellular Fe: 3.4 to $4.2 \times 10^{-16} \mathrm{~mol} \mathrm{Fe}$ cell $^{-1}$ ) in the coastal diatom C. sociale was 3 to 5 times the amounts (minimum intracellular $\mathrm{Fe}$ on growth $\left[Q_{\mathrm{cri}}\right]: \sim 1 \times 10^{-16} \mathrm{~mol} \mathrm{Fe} \mathrm{cell}^{-1}$ ) needed to support maximal cell yields (Fig. 3, Table 2). The high iron uptake and storage capacity in $C$. sociale allows this species to accumulate excess iron at a high concentration of Fe(III)' and to support up to 2.3 cell divisions without any additional iron uptake (Fig. 3B, initial cell density: 10000 cells ml ${ }^{-1}$ at $0 \mathrm{~d}$ ). According to previous work on minimal $\left[Q_{\text {minimal }}\right]$ and maximal $\left[Q_{\text {maximal }}\right]$ intracellular Fe levels (Maldonado \& Price 1996), phytoplankton isolated from oceanic and coastal waters have a ratio ([ $\left.\left.Q_{\text {maximal }}\right] /\left[Q_{\text {minimal }}\right]\right)$ of $15 \pm 9.9$ and $9.33 \pm 7.54$, respectively. If $\left[Q_{\text {minimal }}\right]$ is equal to $\left[Q_{\text {cri }}\right]$, the ratios of 9 to 15 would support 3.2 to 3.9 cell divisions. In the present study, growth of $C$. sociale after the addition of DFB at 1,3 and 5 d cultivations in direct Fe(III) input media (Fig. 2B, initial cell density: 1000 cells ml-1 at $0 \mathrm{~d}_{\text {; intra- }}$ cellular Fe was not measured) continued for 3 to $4 \mathrm{~d}$ up to 3.0 to 3.5 cell divisions $\left\{\log _{2}\left([\mathrm{Cn}] /\left[C_{\mathrm{DFB}}\right]\right)\right\}$. These values were remarkably consistent with those calculated from [ $\left.Q_{\text {maximal }}\right] /\left[Q_{\text {minimal }}\right]$ ratios (9 to 10 ) of phytoplankton isolated from coastal waters (Maldonado \& Price 1996). In addition, the iron uptake rate may have been affected by cell density when iron was directly added to the culture solution, probably resulting in the higher iron uptake rate with the lower cell density (Figs. 2B \& 3, Table 1). However, according to the minimum Fe quota $\left[Q_{\min }\right]$ required for maximum growth rates $\left(\mu_{\max }\right)$ and the maintenance Fe quota $\left[Q_{\text {maint }}\right]$ (= $\left[Q_{\mathrm{cri}}\right]$ in the present study) extrapolated to where growth rate is zero, since cell yields are affected by $\mathrm{DFB}, \mathrm{DFB}$ must cause the growth rate to decrease once the growth rate becomes dependent upon cellular $\mathrm{Fe}$, where $[Q]<\left[Q_{\min }\right]$ but $>\left[Q_{\text {maint }}\right]$. In fact, a slight decrease in the growth rates $\left(\leq \mu_{\max }\right)$ was observed before reaching the maximal cell yields $[\mathrm{Cn}]$ after the addition of DFB (Figs. 2B \& 3B), indicating the existence of $\left[Q_{\min }\right]\left(>\left[Q_{\text {maint }}\right]\right)$ and $\left[Q_{\text {maint }}\right]\left(=\left[Q_{\text {cri }}\right]\right)$.

Sunda (2001) concluded that diatoms can accumulate excess iron during a period of high availability, which can then be drawn upon later to support high growth rates during blooms. The enhanced capacity for iron storage may be an important factor in allowing phytoplankton to out-compete other species during episodic blooms. Such luxury uptake can be especially beneficial where iron concentrations are spatially and temporally variable, such as in many coastal environments, coastal and oceanic upwelling regimes, and oceanic systems receiving episodic eolian iron inputs. It has been reported that the oceanic diatom had a much lower growth requirement for cellular iron than its coastal congener, but the surface area-normalized iron uptake rates of the 2 species were similar (Sunda et al. 1991, Sunda \& Huntsman 1995, 1997). The ability of the oceanic species to outgrow its neritic congener at low iron concentrations was due to its unusually low cellular iron requirement. In the present study, therefore, the oceanic species may have a lower critical concentration of intracellular $\mathrm{Fe}\left(\mathrm{mol} \mathrm{Fe}(\mathrm{mol} \mathrm{C})^{-1}\right)$ for growth than the coastal species. The supply of high concentrated acidic iron solution to iron-limited HNLC regions in iron fertilization experiments may induce luxury iron uptake by coastal and/or large phytoplankton species at high concentrations of bioavailable Fe'.

\section{Dissolution rate and bioavailability of aged am-Fe(III)}

The hydrolytic precipitation rate of $\mathrm{Fe}^{3+}$ in seawater was fast, resulting in an extremely low $0.025 \mu \mathrm{m}$ filterable (dissolved) Fe concentration with short aging time (Fig. 4A). In general, the freshly precipitated am$\mathrm{Fe}(\mathrm{III})$, in which very fine particles with a large surface area and structural disorder occurs, consists of aggregates of hydrated ferric ions that have a very low thermodynamic stability. In the present study, some of the fine particles (polymeric ferric oxyhydroxide species) in the freshly precipitated am-Fe(III) may pass through a $0.025 \mu \mathrm{m}$ filter. Freshly precipitated am-Fe(III) undergoes continuous chemical changes with time (loss of water and increased crystallization) that are not easily quantified. An increase in the thermodynamic stability of am-Fe(III) substantially decreases the solubility and lability of the solid am-Fe(III) phase and thereby decreases iron availability to phytoplankton (Wells et al. 1983, 1991, Kuma \& Matsunaga 1995). The actual particulate solid hydroxide or oxide phase regulates the solubility of dissolved inorganic Fe species [Fe(III)']. In the present study, the solubility measurements of am-Fe(III) in seawater indicated a rapid decrease of dissolved $\mathrm{Fe}$ concentrations with aging time (Fig. 4A), suggesting that am-Fe(III) in seawater solution changes to larger and more stable particles with aging time (Crosby et al. 1983). In addition, lower temperature retarded the conversion to larger particles.

In a previous study (Kuma \& Matsunaga, 1995), proton-promoted dissolution rates of am-Fe(III) decreased rapidly with aging time. In the present study, organic 
ligand (DFB)-promoted dissolution rate of $3 \mathrm{~d}$ aged am$\mathrm{Fe}(\mathrm{III})$ was slower than that of $1 \mathrm{~d}$ aged am-Fe(III) because of the conversion to more stable phases in culture solution with time during culture experiments (Fig. 4B). Organic ligands tend to become adsorbed specifically and to form surface complexes with the Fe(III) Lewis acid centers of the hydrous oxide surface. They also usually form complexes with Fe(III) in solution. Complex formation in solution increases the solubility. The enhancement of the dissolution rate by a ligand in surface-controlled reaction implies that surface complex formation facilitates the release of ions from the surface to the adjacent solution (Stumm 1992). In addition, there was no growth in DFB-Fe(III) (10:1) medium at $10^{\circ} \mathrm{C}$ (Fig. 2A) and $\mathrm{Fe}(\mathrm{III})$ dissociative precipitation of premixed DFB-Fe(III) (10:1) complex in seawater $\left(10^{\circ} \mathrm{C}\right)$ was not observed for $10 \mathrm{~d}$ (Fig. 4B). The rate of DFB-Fe(III) dissociation is quite slow $\left(K_{\mathrm{FeL}, \mathrm{Fe}(\mathrm{III})^{\prime}}=k_{\text {formation }} / k_{\text {dissociation }}=[\mathrm{Fe}(\mathrm{III}) \mathrm{L}] /\left[\mathrm{Fe}(\mathrm{III})^{\prime}\right]\right.$ $\left.\left[\mathrm{L}^{\prime}\right]=10^{16.5} \mathrm{M}^{-1}\right)$. Excess ligand in this experiment (DFB-Fe(III) (10:1)) would rapidly recomplex any librated Fe(III)'. Thus, the steady state concentration of $\mathrm{Fe}(\mathrm{III})^{\prime}$ is several orders of magnitude below the expected range of oxyhydroxide formation, which should preclude the formation of a colloidal precipitate. Therefore, the dissolution of am-Fe(III) by the addition of DFB during incubation in the present study prevented further iron uptake by Chaetoceros sociale from ambient external iron in the culture media. These above results suggest that the bioavailabilty of am$\mathrm{Fe}(\mathrm{III})$ produced in culture solution decreases rapidly with time during culture experiments, resulting from a decreased dissolution rate of am-Fe(III) with time.

\section{Simple model for phytoplankton growth by intracellularly stored Fe in direct Fe(III) input media}

The results of iron uptake and growth rate experiments indicated that the direct Fe(III) input to the culture media induced the highest Fe uptake rate $(\sim 3.4 \times$ $10^{-16} \mathrm{~mol} \mathrm{Fe}$ cell $^{-1} \mathrm{~d}^{-1}$ ) by Chaetoceros sociale during the first day of incubation. The highest specific growth rate $\left(\sim 0.5 \mathrm{~d}^{-1}\right)$ of $C$. sociale was maintained for a few days even after the addition of DFB. The duration of cell division yields and the maximum cell yields appeared to be dependent on the amount of intracellularly stored $\mathrm{Fe}$, suggesting the presence of a critical concentration of intracellular $\mathrm{Fe}$ on phytoplankton growth $\left(\left[Q_{\text {cri }}\right]=\sim 1 \times 10^{-16} \mathrm{~mol} \mathrm{Fe} \mathrm{cell}^{-1}\right.$ for C. sociale). In this model, we simply assumed that $\left[Q_{\mathrm{cri}}\right]$ in the present study is equal to the minimum Fe quota $\left[Q_{\min }\right]$ required for $\mu_{\max }$ and the maintenance Fe quota $\left[Q_{\text {maint }}\right]$ extrapolated to where growth rate is zero $\left(\left[Q_{\mathrm{cri}}\right]=\right.$ $\left.\left[Q_{\min }\right]=\left[Q_{\text {maint }}\right]\right)$, although a slight decrease in the growth rates $\left(\leq \mu_{\max }\right)$ was observed before reaching the maximal cell yields after the addition of DFB (Figs. 2B $\& 3 \mathrm{~B})$ and $\left[Q_{\min }\right]$ is generally $>\left[Q_{\text {maint }}\right]$. In addition, the decrease in cell concentrations after maximal cell yields (Figs. 2B \& 3B) is presumably due to a continuous release of non-bioavailable Fe from cells and a temporal change from dissolved $\mathrm{Fe}$ to the particulate Fe phase. These model assumptions result in maximal cell yields being reached without a decrease in growth rates $\left(\leq \mu_{\max }\right)$ after DFB addition, very similar to the experimental results of phytoplankton growth in the present study. To understand the effect of iron on phytoplankton growth in the present study, we constructed a preliminary iron-based ecosystem model in the direct Fe input media by determining some parameters (i.e. phytoplankton growth, transfer rate from dissolved Fe to particulate $\mathrm{Fe}$, excretion rate of cellular Fe from dead cell).

To interpret the temporal decrease in dissolved Fe concentrations with aging time in the Fe(III) hydrolytic precipitation experiment (Fig. 4A), we present a model assuming a first-order transfer reaction with a rate constant, $k_{1}$, from dissolved Fe to particulate Fe at an early period of rapid $\mathrm{Fe}(\mathrm{III})$ hydrolytic precipitation and a back reaction with a rate constant, $k_{2}$, from unstable fine particulate $\mathrm{Fe}$ to dissolved $\mathrm{Fe}$ in the slow conversion process to more stable particulate Fe with time. Hence a reciprocal of $k_{2}$ is defined as an experimental progress time $t$ as follows:

$$
k_{2}(t)=c_{1} /\left(c_{2}+t\right)
$$

where $c_{1}$ and $c_{2}$ are unknown constant values. In our previous study (Yoshida et al. 2006), we estimated the constant values of $c_{1}$ and $c_{2}$ using a fitting procedure in order to search for the best fit to the temporal change of dissolved Fe concentration $\left(D_{\mathrm{Fe}}\right)$ (Fig. 4A). In our model, $D_{\mathrm{Fe}}$ change calculated with $c_{1}=5.0 \mathrm{~d}$ and $C_{2}=1.5 \mathrm{~d}$ is well consistent with the measured $D_{\mathrm{Fe}}$ change with time in the culture experiment at $10^{\circ} \mathrm{C}$ (Fig. 5, Yoshida et al. 2006). Here, a time-developing model between $D_{\mathrm{Fe}}$ and particulate $\mathrm{Fe}$ concentrations $\left(P_{\mathrm{Fe}}\right)$ is given by:

$$
\begin{gathered}
\mathrm{d} D_{\mathrm{Fe}} / \mathrm{d} t=-k_{1} D_{\mathrm{Fe}}+k_{2}(t) P_{\mathrm{Fe}} \\
\mathrm{d} P_{\mathrm{Fe}} / \mathrm{d} t=k_{1} D_{\mathrm{Fe}}-k_{2}(t) P_{\mathrm{Fe}}
\end{gathered}
$$

We can roughly estimate $k_{1}=30 \mathrm{~d}^{-1}$ from a rapid decrease in $D_{\mathrm{Fe}}\left(100 \mathrm{nmol} \mathrm{l}^{-1}(t=0)\right.$ to $16 \mathrm{nmol} \mathrm{l}^{-1}(t=$ $1 \mathrm{~h})$ with $k_{1}=44 \mathrm{~d}^{-1}$ and to $12 \mathrm{nmol} \mathrm{l^{-1 }}(t=3 \mathrm{~h})$ with $k_{1}$ $=17 \mathrm{~d}^{-1}$ ) at an early stage of the Fe(III) hydrolytic precipitation experiment (Fig. 4A) because of a first-order reaction of hydrolytic precipitation at $k_{1} D_{\mathrm{Fe}}>k_{2} P_{\mathrm{Fe}}$. Initial values of $D_{\mathrm{Fe}}$ and $P_{\mathrm{Fe}}$ at $t=0 \mathrm{~d}$ in the direct $\mathrm{Fe}$ input media are 100 and $0 \mathrm{nmol}^{-1}$, respectively.

We constructed a simple iron-based ecosystem model using the total amount of intracellular Fe $(D a)$ in 


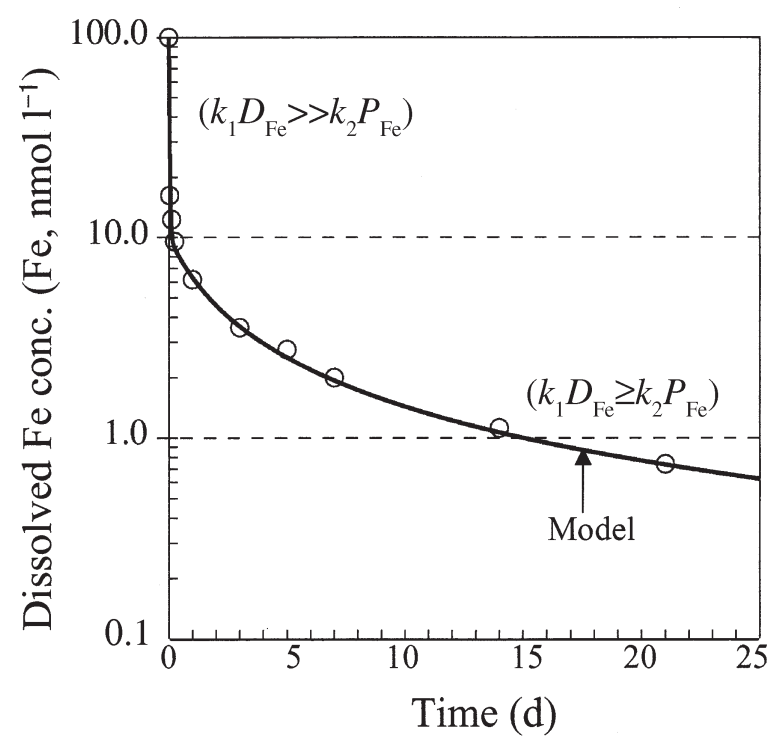

Fig. 5. Hydrolytic precipitation rate model of $\mathrm{Fe}^{3+}$ in seawater with $100 \mathrm{nmol} \mathrm{Fe} \mathrm{l}^{-1}$ at $10^{\circ} \mathrm{C}$ (thick line: hydrolytic precipitation rate model; open circle: observed dissolved Fe concentration). The model assumed a first-order transfer reaction with a rate constant, $k_{1}$, from dissolved $\mathrm{Fe}\left(D_{\mathrm{Fe}}\right)$ to particulate $\mathrm{Fe}\left(P_{\mathrm{Fe}}\right)$ at an early period of rapid Fe(III) hydrolytic precipitation and a back reaction with a rate constant, $k_{2}$, from unstable fine particulate $\mathrm{Fe}$ to dissolved $\mathrm{Fe}$ in the slow conversion process to more stable particulate Fe with time (Yoshida et al. 2006)

phytoplankton and $D_{\mathrm{Fe}}$ and $P_{\mathrm{Fe}}$ in seawater to represent the results of culture experiment $\left(10^{\circ} \mathrm{C}\right)$ in the present study. This system is represented by the following ordinary differential equations. The equations for $D_{\mathrm{Fe}}$ in seawater and $D a$ in phytoplankton can be written as follows:

$$
\begin{gathered}
\mathrm{d} D_{\mathrm{Fe}} / \mathrm{d} t=-\sigma D a-k_{1} D_{\mathrm{Fe}}+k_{2} P_{\mathrm{Fe}} \\
\mathrm{d} D a / \mathrm{d} t=\sigma D a
\end{gathered}
$$

where $D a=D_{\text {radio }}$ in the present study (Fig. 3A, Table 2). The function of $\sigma$ denotes the iron uptake rate by phytoplankton, which is only a function of $D_{\mathrm{Fe}}$ and not limited by light and other nutrients. That is,

$$
\sigma=\sigma_{\max } M
$$

where $\sigma_{\max }$ is the maximum iron uptake rate by phytoplankton and $M$ will show classic saturation kinetics with increased external concentration of $D_{\mathrm{Fe}}$ as expressed by the Michaelis-Menten equation as follows:

$$
M=D_{\mathrm{Fe}} /\left(D_{\mathrm{Fe}}+K\right)
$$

where $K$ is the half-saturation constant for $D_{\mathrm{Fe}}$. In the present study, we used a $K$ value of $1.1 \mathrm{nmol}^{-1}$ for the large chain-forming diatom Chaetoceros dichaeta determined by Timmermans et al. (2001). We assume that the amount of Fe released from the phytoplankton cell after the maximal cell yields is proportional to the total cellular Fe. The value of $0.1 \mathrm{~d}^{-1}$ was roughly estimated as the excretion rate of cellular Fe from the decreasing rate of cell number after the maximal cell yields (Fig. 3B). In our model, we ignored the mortality of phytoplankton and the excretion of cellular Fe during the exponential growth phase before the maximal cell yields.

To examine the cellular Fe concentration cell ${ }^{-1}$, we counted the model's phytoplankton cell number $(\mathrm{Cn})$ following:

$$
\mathrm{d} C n / \mathrm{d} t=\sigma_{\mathrm{c}} C n
$$

where $\sigma_{\mathrm{C}}$ is a growth rate of phytoplankton. Simply, we consider that $\sigma_{\mathrm{c}}$ is the same as $\sigma_{\max }$. The value of $\sigma_{\max }=\sigma_{\mathrm{c}}$ can be a typical apparent growth rate $\left(0.5 \mathrm{~d}^{-1}\right)$ measured during culture experiments in the direct Fe(III) input media (Figs. 2B \& 3B, Table 1). In our model, we simply used the growth rate $\left(\sim 0.5 \mathrm{~d}^{-1}\right)$ observed in the iron uptake and growth rate experiments (Fig. 3B, Table 1).

Although the highest $\sigma$ by phytoplankton was observed at the initial stage in the long-term iron uptake experiments in the direct Fe(III) input media (Fig. 3A), the maximum uptake rate at $t$ close to $0 \mathrm{~d}$ cannot be determined. Therefore, we estimated a model's initial value of Fe uptake with $3.9 \mathrm{nmol} \mathrm{l}^{-1}$ at $t=0.5 \mathrm{~d}$ in the culture experiments in the direct Fe(III) input media (no DFB, DFB (1 d) and DFB (3 d)) from reverse calculation using a simple exponential growth rate with $\sigma_{\mathrm{C}}=$ $0.5 \mathrm{~d}^{-1}$ and the experimental value of Fe uptake with $D a=5 \mathrm{nmol} \mathrm{l}^{-1}$ at $t=1 \mathrm{~d}$ (Fig. 3A). In the case of $1 \mathrm{~d}$

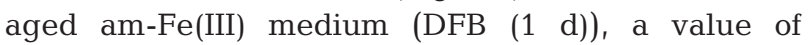
$2.3 \mathrm{nmol} \mathrm{l}^{-1}$ at $t=0.5 \mathrm{~d}$ was estimated from the value of Fe uptake with $D a=3 \mathrm{nmol}^{-1}$ at $t=1 \mathrm{~d}$ (Fig. 3A). In addition, a cell number of $C n=12840$ cells $\mathrm{ml}^{-1}$ at $t=$ $0.5 \mathrm{~d}$ was estimated from an exponential growth rate $\left(0.5 \mathrm{~d}^{-1}\right)$ and $C n=10000$ cells $\mathrm{ml}^{-1}$ at $t=0 \mathrm{~d}$. The $D_{\mathrm{Fe}}$ and $P_{\mathrm{Fe}}$ values of 7.8 and $92.2 \mathrm{nmol} \mathrm{l}^{-1}$, respectively, at $t=0.5 \mathrm{~d}$ were easily calculated from time-developing model equations (Eqs. 4 \& 5) (Fig. 5). The growth conditions for $D a$ and $C n$ are as follows: (1) $\sigma_{\max }=0.0 \mathrm{~d}^{-1}$, no further iron uptake from external iron by phytoplankton after addition of DFB and (2) $\sigma_{\mathrm{C}}=0.0 \mathrm{~d}^{-1}$, no growth below a critical concentration of intracellular Fe (total amount of intracellular Fe cell-1: $\mathrm{Da} / \mathrm{Cn}$ ) on phytoplankton growth. We could simulate temporal changes of $D a$ and $C n$ using a value of $[\mathrm{Da} / \mathrm{Cn}]=\left[Q_{\mathrm{cri}}\right]$ $=1 \times 10^{-16}$ mol Fe cell ${ }^{-1}$ defined as a critical concentration of intracellular Fe cell ${ }^{-1}$ ([ $\left.Q_{\text {cri }}\right]$, Table 2).

Fig. 6 presents the changes in $\mathrm{Da}, \mathrm{Da} / \mathrm{Cn}$ and $\mathrm{Cn}$ with time, resulting from the simulation of our model. The phytoplankton growth rates and maximal cell yields in the direct Fe(III) input media (no DFB, DFB (1 d) and DFB (3 d)) and $1 \mathrm{~d}$ aged am-Fe(III) medium (DFB (1 d)) obtained from our model (Fig. 6C) are similar to those observed in the culture experiments 

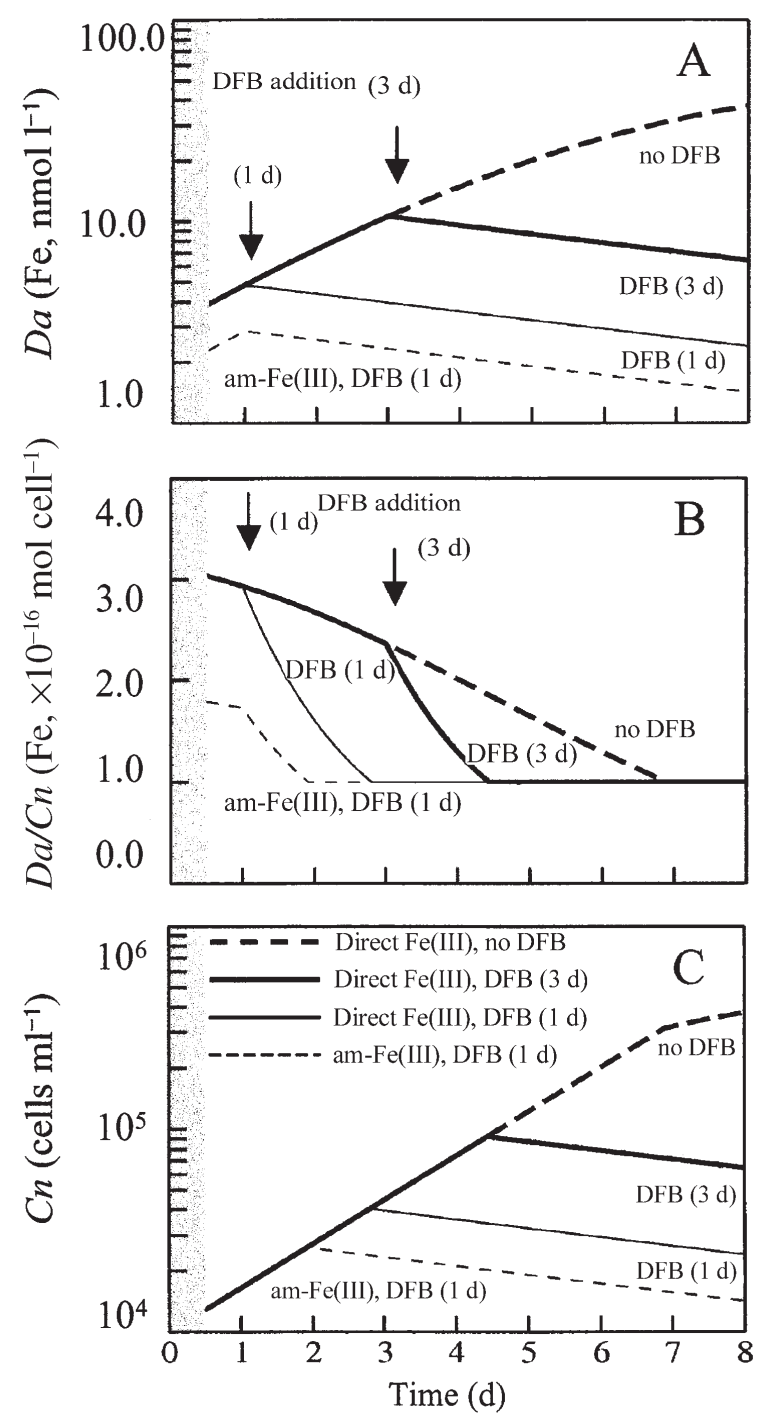

Fig. 6. Time-course models of (A) Fe uptake (Da), (B) intracellular Fe concentration cell ${ }^{-1}(\mathrm{Da} / \mathrm{Cn})$ and $(\mathrm{C})$ cell number $(\mathrm{Cn})$ in the direct Fe(III) input media (no DFB, DFB (1 d) and DFB (3 d)) and $1 \mathrm{~d}$ aged am-Fe(III) medium (DFB (1 d)) during the cultivation. Maximum uptake rate at $t \approx 0 \mathrm{~d}$ cannot be determined and is indicated by the stippled area on the left of each panel

(Figs. 2B \& 3B). The similarity suggests that the growth rate of phytoplankton is independent of the amount of intracellularly stored $\mathrm{Fe}$, above a critical concentration of intracellular Fe on the growth, and the maximal cell yields ([Cn]) are controlled by a critical intracellular Fe $\left([\mathrm{Da} / \mathrm{Cn}]=\left[Q_{\mathrm{cr}}\right]\right)$. However, maximum cell concentration (approximately 300000 cells ml ${ }^{-1}$ at 7 d, Fig. 6C) in the direct Fe(III) input medium (no DFB) obtained from our model is remarkably different from that in the culture experiment $\left(126000 \pm 20000\right.$ cells ml $^{-1}$ at $5 \mathrm{~d}$, Fig. 3B and Table 1) probably because of the rapid decrease in bioavailability of hydrolytic precipitated Fe with time in the medium (Kuma \& Matsunaga 1995) and/or the change of chemical environment in the culture solution during cultivation experiments.

Our results suggest that the high iron uptake and storage capacity in phytoplankton allows them to accumulate excess iron at a high concentration of bioavailabe $\mathrm{Fe}^{\prime}\left(\mathrm{Fe}(\mathrm{II})^{\prime}\right.$ and $\left.\mathrm{Fe}(\mathrm{III})^{\prime}\right)$ in estuarine mixing systems and coastal waters and in mesoscale iron fertilization experiments. The high supply of $\mathrm{Fe}^{\prime}$ in marine environments is one of the most important mechanisms for providing bioavailable $\mathrm{Fe}^{\prime}$ into these environments. The luxury iron uptake and the presence of critical intracellular Fe concentration per cell on phytoplankton growth are important factors in supporting high growth rates during blooms. DFB treatment during incubation in the Fe input media is a unique technique for measuring the iron uptake and storage capacity in phytoplankton by preventing further iron uptake from external iron in the culture media.

Acknowledgements. We are grateful to the anonymous reviewers for their constructive and helpful comments on this work. This study was partially supported by grants for Environmental Research (No. 023039) from the Sumitomo Foundation and for Scientific Research (No. 17651001) from the Ministry of Education, Culture, Sports, Science and Technology, Japan.

\section{LITERATURE CITED}

Anderson MA, Morel FMM (1982) The influence of aqueous iron chemistry on the uptake of iron by the coastal diatom Thalassiosira weissflogii. Limnol Oceanogr 27:789-813

Archer DE, Johnson KS (2000) A model of the iron cycle in the ocean. Global Biogeochem Cycle 14:269-279

Boyd PW, Watson AJ, Law CS, Abraham ER and 31 others (2000) A mesoscale phytoplankton bloom in the polar Southern Ocean stimulated by iron fertilization. Nature 407:695-702

Boyd PW, Law CS, Wong CS, Nojiri Y and 34 others (2004) The decline and fate of an iron-induced subarctic phytoplankton bloom. Nature 428:549-553

Brezonik PL (1994) Chemical kinetics and process dynamics in aquatic systems. Lewis, Boca Raton, FL

Campbell PGC (1995) Interactions between trace metals and aquatic organisms: a critique of the free-ion activity model. In: Tessier A, Turner DR (eds) Metal speciation and bioavailability in aquatic systems. Wiley, New York, p 45-102

Chen M, Wang WX (2004) Phase partitioning and solubility of iron in natural seawater controlled by dissolved organic matter. Global Biogeochem Cycles 18: GB4013, doi: 10.1029/2003GB002160

Coale KH, Johnson KS, Fitzwater SE, Gordon RM and 15 others (1996) A massive phytoplankton bloom induced by an ecosystem-scale iron fertilization experiment in the equatorial Pacific Ocean. Nature 383:495-501

Croot PL, Johansson M (2000) Determination of iron speciation by cathodic stripping voltammetry in seawater using the competing ligand 2-(2-Thiazolylazo)-p-cresol (TAC). Electroanalysis 12:565-576

Croot PL, Laan P (2002) Continuous shipboard determination 
of $\mathrm{Fe}(\mathrm{II})$ in polar waters using flow injection analysis with chemiluminescence detection. Anal Chim Acta 466: 261-273

Croot PL, Bowie AR, Frew RD, Maldonado MT and 5 others (2001) Retention of dissolved iron and Fe(II) in an iron induced Southern Ocean phytoplankton bloom. Geophys Res Lett 28:3425-3428

Crosby SA, Glasson DR, Cuttler AH, Butler I, Turner DR, Whitfield M, Millward GE (1983) Surface area and porosities of Fe(III)- and Fe(II)-derived oxyhydroxides. Environ Sci Technol 17:709-713

Guillard RRL, Ryther JH (1962) Studies of marine planktonic diatoms. I. Cyclotella nana Hustedt and Detonula confervacea (Gleve) Gran. Can J Microbiol 8:229-239

Hudson RJM, Morel FMM (1989) Distinguishing between extra- and intracellular iron in marine phytoplankton. Limnol Oceanogr 34:1113-1120

Hudson RJM, Morel FMM (1990) Iron transport in marine phytoplankton: kinetics of cellular and medium coordination reactions. Limnol Oceanogr 35:1002-1020

Hudson RJM, Covault DT, Morel FMM (1992) Investigations of iron coordination and redox reactions in seawater using ${ }^{59} \mathrm{Fe}$ radiometry and ion-pair solvent extraction of amphiphilic iron complexes. Mar Chem 38:209-235

Hutchins DA, Franck VM, Brzezinski MA (1999a) Inducing phytoplankton iron limitation in iron-replete coastal waters with a strong chelating ligand. Limnol Oceanogr 44:1009-1018

Hutchins DA, Witter AE, Butler A, Luther GW III (1999b) Competition among marine phytoplankton for different chelated iron species. Nature 400:858-861

Johnson KS, Gordon RM, Coale KH (1997a) What controls dissolved iron concentrations in the world ocean? Mar Chem 57:137-161

Johnson KS, Gordon RM, Coale KH (1997b) What controls dissolved iron concentrations in the world ocean? Authors' closing comments. Mar Chem 57:181-186

Kuma K, Matsunaga K (1995) Availability of colloidal ferric oxides to coastal marine phytoplankton. Mar Biol 122: $1-11$

Kuma K, Nakabayashi S, Matsunaga K (1995) Photoreduction of Fe(III) by hydroxycarboxylic acids in seawater. Water Res 29:1559-1569

Kuma K, Nishioka J, Matsunaga K (1996) Controls on iron(III) hydroxide solubility in seawater: the influence of $\mathrm{pH}$ and natural organic chelators. Limnol Oceanogr 41:396-407

Kuma K, Katsumoto A, Kawakami H, Takatori F, Matsunaga K (1998a) Spatial variability of Fe(III) hydroxide solubility in the water column of the northern North Pacific Ocean. Deep-Sea Res I 45:91-113

Kuma K, Katsumoto A, Nishioka J, Matsunaga K (1998b) Sizefractionated iron concentrations and Fe(III) hydroxide solubilities in various coastal waters. Estuar Coast Shelf Sci 47:275-283

Kuma K, Tanaka J, Matsunaga K (1999) Effect of natural and synthetic organic-Fe(III) complexes in an estuarine mixing model on iron uptake and growth of a coastal marine diatom, Chaetoceros sociale. Mar Biol 134:761-769

Kuma K, Tanaka J, Matsunaga K, Matsunaga K (2000) Effect of hydroxamate ferrisiderophore complex (ferrichrome) on iron uptake and growth of a coastal marine diatom, Chaetoceros sociale. Limnol Oceanogr 45:1235-1244

Kuma K, Isoda Y, Nakabayashi S (2003) Control on dissolved iron concentrations in deep waters in the western North Pacific: iron(III) hydroxide solubility. J Geophys Res 108(C9), 3289, doi:10.1029/2002JC001481

Liu X, Millero FJ (1999) The solubility of iron hydroxide in sodium chloride solutions. Geochim Cosmochim Acta 63: $3487-3497$

Liu X, Millero FJ (2002) The solubility of iron in seawater. Mar Chem 77:43-54

Maldonado MT, Price NM (1996) Influence of N substrate on Fe requirements of marine centric diatoms. Mar Ecol Prog Ser 141:161-172

Maldonado MT, Price NM (1999) Utilization of iron bound to strong organic ligands by plankton communities in the subarctic Pacific Ocean. Deep-Sea Res II 46:2447-2473

Maldonado MT, Price NM (2000) Nitrate regulation of Fe reduction and transport by Fe-limited Thalassiosira oceanica. Limnol Oceanogr 45:814-826

Maldonado MT, Price NM (2001) Reduction and transport of organically bound iron by Thalassiosira oceanica (Bacillariophyceae). J Phycol 37:298-309

Martin JH, Coale KH, Johnson KS, Fitzwater SE and 43 others (1994) Testing the iron hypothesis in ecosystems of the equatorial Pacific Ocean. Nature 371:123-129

Millero FJ (1998) Solubility of Fe(III) in seawater. Earth Planet Sci Lett 154:323-329

Millero FJ, Sotolongo S, Izaguirre M (1987) The oxidation of Fe(II) in seawater. Geochim Cosmochim Acta 51:793-801

Morel FMM, Rueter JG, Anderson DM, Guillard RRL (1979) Aquil: a chemically defined phytoplankton culture medium for trace metal studies. J Phycol 15:135-141

Nakabayashi S, Kusakabe, Kuma K, Kudo I (2001) Vertical distributions of iron(III) hydroxide solubility and dissolved iron in the northwestern North Pacific Ocean. Geophys Res Lett 28:4611-4614

Obata H, Karatani H, Nakayama E (1993) Automated determination of iron in seawater by chelating resin concentration and chemiluminescence detection. Anal Chem 65: 1524-1528

Obata H, Karatani H, Matsui M, Nakayama E (1997) Fundamental studies for chemical speciation of iron in seawater with an improved analytical methods. Mar Chem 56:97-106

Rue EL, Bruland KW (1995) Complexation of Fe(III) by natural organic ligands in the central North Pacific as determined by a new competitive ligand equilibration adsorptive cathodic stripping voltammetric method. Mar Chem 50: $117-138$

Santana-Casiano JM, Gonzalez-Davila M, Rodriguez MJ, Millero FJ (2000) The effect of organic compounds in the oxidation kinetics of Fe(II). Mar Chem 70:211-222

Shaked Y, Kutsuka AB, Morel FMM (2005) A general kinetic model for iron acquisition by eukaryotic phytoplankton. Limnol Oceanogr 50:872-882

Soria-Dengg S, Horstmann U (1995) Ferrioxamines B and E as iron sources for the marine diatom Phaeodactylum tricornutum. Mar Ecol Prog Ser 127:269-277

Stumm W (1992) Chemistry of the solid-water interface. Wiley-Interscience, New York

Stumm W, Morgan JJ (1996) Aquatic chemistry, 3rd edn. Wiley-Interscience, New York

Sunda WG (2001) Bioavailability and bioaccumulation of iron in the sea. In: Turner DR, Hunter KA (eds) The biogeochemistry of iron in seawater. Wiley, New York, p 41-84

Sunda WG, Huntsman SA (1995) Iron uptake and growth limitation in oceanic and coastal phytoplankton. Mar Chem 50:189-206

Sunda WG, Huntsman SA (1997) Interrelated influence of iron, light and cell size on marine phytoplankton growth. Nature 390:389-392

Sunda WG, Swift DG, Huntsman SA (1991) Low iron requirement for growth in oceanic phytoplankton. Nature 351: $55-57$ 
Tani H, Nishioka J, Kuma K, Takata H, Yamashita Y, Tanoue E, Midorikawa T (2003) Iron(III) hydroxide solubility and humic-type fluorescent organic matter in the deep water column of the Okhotsk Sea and the northwestern North Pacific Ocean. Deep-Sea Res I 50:1063-1078

Timmermans KR, Gerringa LJA, de Baar HJW, van der Wagt B, Veldhuis MJW, de Jong JTM, Croot PL, Boye M (2001) Growth rates of large and small Southern Ocean diatoms in relation to availability of iron in natural seawater. Limnol Oceanogr 46:260-266

Tsuda A, Takeda S, Saito H, Nishioka J and 22 others (2003) A mesoscale iron enrichment in the Western subarctic Pacific induces a large centric diatom bloom. Science 300:958-961

Waite TD (2001) Thermodynamics of the iron system in seawater. In: Turner DR, Hunter KA (eds) The biogeochemistry of iron in seawater. Wiley, New York, p 291-342

Wells ML (1999) Manipulating iron availability in nearshore

Editorial responsibility: Paul J. Harrison,

Kowloon, Hong Kong, SAR waters. Limnol Oceanogr 44:1002-1008

Wells ML, Zorkin NG, Lewis AG (1983) The role of colloid chemistry in providing a source of iron to phytoplankton. J Mar Res 41:731-746

Wells ML, Mayer LM, Guillard RRL (1991) A chemical method for estimating the availability of iron to phytoplankton in seawater. Mar Chem 33:23-40

Wells ML, Price NM, Bruland KW (1994) Iron limitation and the cyanobacterium Synechococcus in equatorial Pacific waters. Limnol Oceanogr 39:1481-1486

Wu J, Boyle E, Sunda WG, Wen LS (2001) Soluble and colloidal iron in the oligotrophic North Atlantic and North Pacifc. Science 293:847-849

Yoshida M, Kuma K, Iwade S, Isoda Y, Takata H, Yamada M (2006) Effect of aging time on the availability of freshly precipitated ferric hydroxide to coastal marine diatoms. Mar Biol 149:379-392

Submitted: June 10, 2005; Accepted: February 27, 2006

Proofs received from author(s): June 12, 2006 